\title{
Primary Jurisdiction: A General Theory and Its Application to the Securities Exchange Act
}

\author{
Richard M. Travis $†$
}

The United States Supreme Court in Ricci v. Chicago Mercantile Exchange expanded the doctrine of primary jurisdiction beyond its traditional statutory bases and focused instead upon the ways in which prior administrative determination may aid a court's own decisionmaking processes. After an historical analysis of the development of the primary jurisdiction doctrine, the author expands upon the factors implicit in the Court's "material aid" test, which concern analytical preprocessing, judicial and governmental efficiency, and fairness to the particular parties. Finally, the full range of judicial options now available is applied to a variety of problems under the Securities Exchange Act of 1934.

Primary jurisdiction is a doctrine of judicial administration that provides guidance regarding whether a court should allow an agency an initial opportunity to decide an issue in a case over which the court and the agency have concurrent jurisdiction. ${ }^{1}$ When a defendant moves for a stay or dismissal ${ }^{2}$ on the ground that an issue should be decided first by the agency administering the relevant regulatory statute (i.e., that the agency has primary jurisdiction concerning this issue), the court inust decide whether to proceed with the case, sever the contested issue, stay the proceeding, or dismiss the action. ${ }^{3}$ Although it is often

† A.B. 1965, Harvard University; M.B.A. 1974, University of California, Berkeley; J.D. 1975, Boalt Hall School of Law, University of California, Berkeley.

1. See generally 3 K. Davis, ADMTnISTRative LAW Treatise $\$ \$ 19.01-.09$ (1958, Supp. 1970) [hereinafter cited as Davis, with volume indicated]; L. JAFFE, JUDICuLL CONTROL OF ADMINISTRATIVE ACTION 121-51 (1965) [hereinafter cited as JAFFE]; Convisser, Primary Jurisdiction: The Rule and Its Rationalizations, 65 YALE L.J. 315 (1956); Jaffe, Primary Jurisdiction, 77 HaRv. L. Rev. 1037 (1964); von Mehren, The Antitrust Laws and Regulated Industries: The Doctrine of Primary Jurisdiction, 67 HARV. L. Rev. 929 (1954).

2. Motions to stay or dismiss are made under Fed. R. Crv. P. 12(b) and 12(c), respectively, or possibly under Fed. R. Civ. P. 7. See 2A J. Moore, Federal Practice II $12.02 \mathrm{n} .3$ (2d ed. 1974). Review of a ruling on the motion may be had under 28 U.S.C. $\$ 1651$ or $\$ 1292$ (b) (1970), but not under $\$ 1291$. Thill Sec. Corp. v. NYSE, 469 F.2d 14, 17 (7th Cir. 1972).

3. The usual analysis of severance under FeD. R. Crv. P. 42(b) controls. See 5 J. MOORE, FeDeral Practice $\llbracket 42.03$ (2d ed. 1974). A related inquiry into whether 
stated that the primary jurisdiction doctrine decides only which body (court or agency) is to have priority in time, ${ }^{4}$ the separate question as to the scope of judicial review regarding substance is inevitably and properly drawn into the analysis. ${ }^{5}$ An essential part of any inquiry into this area of law concerns the delicate relationship between deferral in time to agency action and deferral to agency resolution on the merits.

The concept of primary jurisdiction originated in a set of United States Supreme Court cases $^{b}$ centering around the administration of the Interstate Commerce Act, ${ }^{7}$ which provided for extensive regulation of interstate transportation industries. At issue was the reasonableness of particular railway rates. It was clear from the Act that Congress had created the Interstate Commerce Commission (ICC) for the precise purpose of determining such issues. ${ }^{8}$ The Court, therefore, referred decision on those questions to that agency. These cases developed a theory of primary jurisdiction which is properly called "exclusive jurisdiction over the issue." This concept means that, based

the issues sought to be deferred are sufficiently related to the controlling issues in the court case is considered infra at notes 115-18.

The typical result is a stay, which operates to preserve the rights of the parties, particularly with regard to the statute of limitations. See, e.g., General Am. Tank Car Corp. v. El Dorado Terminal Co., 308 U.S. 422, 433 (1940); Laveson v. Trans World Airlines, Inc., 471 F.2d 76, 84 (3d Cir. 1972); Atchison T. \& S.F. Ry. v. Aircoach Transp. Ass'n, 253 F.2d 877, 886 (D.C. Cir. 1958); S.S.W., Inc. v. Air Transp. Ass'n of America, 191 F.2d 658, 664 (D.C. Cir. 1951), cert. denied, 343 U.S. 955 (1952).

Dismissal will result only if all issues including the remedy are solely for the agency or if there will be no prejudice to the plaintiff in so doing. Far East Conf. v. United States, 342 U.S. 570,577 (1952). The latter basis will be relevant if the relief sought is only an injunction, so that there is no problem of tolling the statute of limitations.

4. 3 Davis, supra note $1, \$ 19.01$ at 3.

5. "Binding" agency decisions generally remain subject to judicial review under the Administrative Procedure Act, 5 U.S.C. $\$ \$ 701-06$ (1970) [hereinafter cited as APA], or the particular regulatory statute. This review covers such items as substantial evidence to support factual findings, arbitrariness, questions of law and protection of constitutional rights. See generally 4 Davis, supra note 1, $\$ \S 29.01-11$. Thus, the terıns "binding" and "exclusive" do not nean that judicial review is conıpletely unavailable. Id. $\$ \S 28.01-.21$; Cf. Pogue, Exclusive Jurisdiction, 43 ANTITRUst L.J. 313, 317 (1974).

6. Keogh v. Chicago \& N.W. Ry., 260 U.S. 156 (1922); Great N. Ry. v. Merchants Elevator Co., 259 U.S. 285 (1922); Northern Pac. Ry. v. Solum, 247 U.S. 477 (1918); Texas \& Pac. Ry. v. Abilene Cotton Oil Co., 204 U.S. 426 (1907). The first case to use the term "primary jurisdiction" was ICC v. Chicago, R.I. \& Pac. Ry., 218 U.S. 88, 110 (1910) (McKenna, J.). The first case to utilize a stay while referring a single issue to an agency was Mitchell Coal \& Coke Co. v. Pennsylvania R.R., 230 U.S. 247, 256 (1912).

7. 49 U.S.C. $\S \S 1-27(1970)$.

8. Texas \& Pac. Ry. v. Abilene Cotton Oil Co., 204 U.S. 426, 448 (1907).

9. "[T] the test is whether some parts of the case are within the exclusive jurisdiction of the agency." 3 Davts, supra note $1, \$ 19.07$ at 39 . The doctrine applies at the level of particnlar issues. Israel v. Baxter Laboratories, Inc., 466 F.2d 272, 281 (D.C. Cir. 1972). An agency need not have power over the issue of relief, so long 
upon statutory interpretation, it would be improper for a court to decide the contested substantive issue.

Where a regulatory pattern is less pervasive than that found in the Interstate Commerce Act, exclusive jurisdiction over an issue may not be certain. In such a case the court may defer in time while reserving to itself the possibility of ultimately deciding the substantive issue after an agency proceeding has developed the facts. ${ }^{10}$ This is particularly appropriate where conduct seemingly violative of antitrust provisions is subject to independent regulation and sanctioming by an administrative agency. In Carnation Co. v. Pacific Westbound Conference, ${ }^{11}$ the Supreme Court held that deferral to an agency was appropriate if the conduct was "arguably lawful" under the regulatory statute. ${ }^{12}$ Deferral may avoid the risks of conflict and interference between the two bodies and may ultimately help the court in deternining whether Congress intended the agency to have exclusive regulatory power. This approach avoided the choice between refusing to defer and giving bimding effect to the agency result, although the theory remained grounded in statutory coustruction. Even after Carnation, however, the doctrine remained unsuitable for precise application to agencies whose authorizing statutes did not mandate substantive deferral.

In 1973, the Supreme Court, in Ricci v. Chicago Mercantile Exchange, ${ }^{13}$ passed over exclusive jurisdiction as a rationale and focused on the contribution to a court's own decisionmaking afforded by an agency record. It held that a court should defer hearing an antitrust case if prior agency determination of one issue (violation of selfregulatory rules and the statute) would be of "material aid" to the court's ultimate decision on another issue (antitrust immunity). The significance of Ricci is twofold. First, it gives explicit recognition to the option of deferral even when there is no possibility that the administrative decision will be binding. Second, it indicates that lower courts should make generous use of available agency procedures. Combined with the traditioulal grounds for deferral, Ricci suggests solutions to the jurisdictional problems raised by a wide variety of statutory and factual patterns.

as the issue which is referred is committed to it by statute. General American Tank Car Corp. v. El Dorado Terminal Co., 308 U.S. 422, 433 (1940); District Council v. Seatrain Lines, Inc., 377 F. Supp. 1278 (E.D. Pa. 1973); Delaware River Port Authority v. United States Lines, Inc., 331 F. Supp. 441 (E.D. Pa. 1971).

10. Though it reserved final power to decide the substantive issue, the court may later recognize the agency result as binding (as a result of exclusive jurisdiction) or agree with the agency decision even though it is not binding.

11. 383 U.S. 213, modified, 383 U.S. 932 (1966).

12. See text accompanying notes 70-78 infra, for an explanation of this test.

13. 409 U.S. 289 (1973) (White, J.) (5-4 decision). 
This Comment seeks to provide a principled framework for analysis of the issues within primary jurisdiction, with emphasis on the process of statutory construction which formed the basis of the traditional doctrine and on the factors which a court may consider in its discretion when exclusive jurisdiction over an issue is uncertain. Part I discusses the preliminary requirement of concurrent jurisdiction. The next three parts discuss theories of deferral in the context of their historical development: Part II reviews exclusive jurisdiction over the issue, a concept that formed the original doctrinal basis for primary jurisdiction; Part III examines the "arguably lawful" test that serves as a ineans of evaluating deferral in cases where exclusive jurisdiction is uncertain; Part IV analyzes the "material aid" test, especially as articulated in Ricci, which for the first time explicitly allows deferral for agency findings even when the resulting agency determination will not be binding. Finally, these three theories are illustrated by their application to an array of actual and hypothetical cases under the Securities Exchange Act of $1934,{ }^{14}$ an area of self-regulation in which the doctrine of prinary jurisdiction has been infrequently applied.

\section{$\mathrm{I}$}

\section{CONCURRENT JURISDICTION}

The model of primary jurisdiction presumes a procedural posture which may be denoted as concurrent jurisdiction over the controversy. If the court lacks jurisdiction, the agency has already acted, or there is no available procedure to bring the issue before the agency, the doctrine does not apply. For example, if a court does not have subject matter jurisdiction over at least one cause of action in a dispute where agency jurisdiction is present, the case will be dismissed. Such cases are wholly within the exclusive jurisdiction of an agency. ${ }^{15}$ On the other hand, if the agency has already acted with reference to the specific dispute, either by adjudication between the parties or by interpreting the rules or tariffs in relation to the narrow issue before the court, there is no reason to defer: ${ }^{16}$ "[TT]he [agency] has done its full

14. 15 U.S.C. $\$ \$ 78 \mathrm{a}$ to $78 \mathrm{hh}-1$ (1970).

15. See, e.g., Terminal Warehouse Co. v. Pennsylvania R.R., 297 U.S. 500 (1936); United States Navigation Co. v. Cunard S.S. Co., 284 U.S. 474 (1932); Keogh v. Chicago \& N.W. Ry., 260 U.S. 156 (1922); Texas \& Pac. Ry. v. Abilene Cotton Oil Co., 204 U.S. 426 (1907). The distinguishing characteristic of these cases is the conclusion that the administrative remedy supersedes the cause of action. See Pogue, Exclusive Jurisdiction, 43 ANTITRUST L.J. 313 (1974).

16. United States v. Western Pac. R.R., 352 U.S. 59, 69 (1956); Shew v. Southland Corp., 370 F.2d 376, 380 (5th Cir. 1966); Strickland Transp. Co. v. United States, 334 F.2d 172 (5th Cir. 1964) (ICC had clarified factors underlying tariff construction in three cases); Agar Food Products Co. v. Chicago River \& I.R.R., 358 F. Supp. 1312 
task"; "there is nothing further to be remanded."17 The classification is of course a matter of degree, for the agency action is often slightly distinguishable or sufficiently removed in time to warrant re-examination.

Resolution of the jurisdictional issue turns upon interpretation of the statute granting power to the agency and the agency rules of practice. Although the agency may otherwise have broad discretionary powers, the statute may not give subject matter jurisdiction over a particular issue. ${ }^{18}$ Or, even if the agency has statutory jurisdiction, its own rules may reflect a decision not to deal with every kind of case. For example, the NLRB will not accept cases involving businesses whose sales are below a certaim amount. ${ }^{19}$ Another possibility is that the issue can be decided only in a particular context. The NLRB can decide the question of whether or not a provision is a mandatory bargaining subject, but only in the context of a "refusal to bargain."20

Narrow interpretations of the jurisdiction of the agency are likely to be used by courts reluctant to defer. Such courts inay also stress the absence of assurance that the agency will take action, ${ }^{21}$ since a refusal to take action may result from exercise of the agency's discretionary jurisdiction ${ }^{22}$ or from plamtiffs' failure to satisfy certain standing requirements. ${ }^{23}$ Proponents of administrative determination, on the

(N.D. Ill. 1973) (prior ICC rulings sufficiently clear); cf. Ratner v. Chemical Bank N.Y. Trust Co., 309 F. Supp. 983, 988 (S.D.N.Y. 1970) (Federal Reserve Board had issued policy stateinent on interpretation of regulations).

The doctrine does not apply where the agency itself is the plaintiff, because delay would be pointless where the statute is not being bypassed. CAB v. Aeromatic Travel Corp., 489 F.2d 251 (2d Cir. 1974). But the doctrine may apply if the agency files an amicus brief in support of the plaintiff as long as the issue is one committed to the agency by statute. Trans-Pacific Airlines, Ltd. v. Hawaiian Airlines, Ltd., 174 F.2d 63 (9th Cir. 1949).

17. Aloha Airlines, Inc. v. Hawaiian Airlines, Inc., 489 F.2d 203, 211, 212 (9th Cir. 1973), cert. denied, 417 U.S. 913 (1974).

18. See, e.g., FMC v. Seatrain Lines, Inc., 411 U.S. 726 (1973), aff'g 460 F.2d 932 (D.C. Cir. 1972), which held that the Federal Maritime Commission's antitrust exeinption powers under 46 U.S.C. $\$ 814$ (1970) did not extend to approval of one-shot merger agreements not requiring continuous regulatory supervision.

19. These jurisdictional standards were originally set forth in 26 L.R.R.M. 50 (1950) and revised in 34 L.R.R.M. 75 (1954) and 42 L.R.R.M. 96 (1958).

20. Local 189, Amalgamated Meat Cutters v. Jewel Tea Co., 381 U.S. 676, 687 (1965).

21. Id.

22. The NLRB asserted a discretionary power to decline to take cases involving "essentially local commerce" under section 10(a) of the NLRA, 29 U.S.C. $\$ 160$ (a) (1970). Such power was approved in Haleston Drug Stores, Inc. v. NLRB, 187 F.2d 418 (9th Cir. 1951); but it is subject to judicial review. Johiet Contractors Ass'n v. NLRB, 193 F.2d 833 (7th Cir. 1952).

23. For example, section 5 of the Federal Trade Commission Act, 15 U.S.C. $\S$ 45 (1970), does not provide a private remedy. The aggrieved person can only bring the matter to the attention of the FTC, which has complete discretion on whether or 
other hand, have argued that deferral should not necessarily be refused when an agency may reject jurisdiction since reason to defer may still be found in the "risk of interference" or "inaterial aid" theories which underlie the doctrine. ${ }^{24}$ If the agency does refuse to act, the case will continue in court. $^{25}$

Agency jurisdiction in the sense of authority to decide the case is not necessarily a prerequisite for deferral. ${ }^{26}$ In several cases the agency went out of its way to assist the court, with court approval, even though the agency could not have originally entertained the case. ${ }^{27}$ Likewise, running of the agency's own statute of limitations need not be a bar, so long as the remedy sought is a judicial one and the doctrine operates to refer only limited issues from the court case. ${ }^{28}$ These cases can be classified as ones in which the controverted issue was one typically decided by the agency, but in which it had no power to grant the reinedy sought. ${ }^{29}$ Deferral may be rationalized by calling the

not to prosecute. FTC v. Klesner, 280 U.S. 19, 25 (1929). Another example is that under section 1, paragraphs 18 to 20 of the Interstate Commerce Act, 49 U.S.C. $\$$ $1(18)-(20)$ (1970) [hereinafter cited as ICA], a party opposed to new construction has no standing to initiate a proceeding, although such a party may intervene if an application is filed. Texas \& Pac. Ry. v. Gulf, C. \& S.F.R.R., 270 U.S. 266 (1926). These patterns are to be contrasted to the scheme of section 13(1) of the ICA, 49 U.S.C. $\$$ 13(1) (1970), which provides that "any person" may file a complaint and the ICC must investigate if there is "reasonable ground" to do so.

24. Laveson v. Trans World Airlines, 471 F.2d 76, 83 n.50 (3d Cir. 1972) (applying an arguably lawful test to the issue of jurisdiction); Wheelabrator Corp. v. Chafee, 455 F.2d 1306, 1316 (D.C. Cir. 1971); Brawner Bldg., Inc. v. Shehyn, 442 F.2d 847, 855-57 (D.C. Cir. 1971); J.M. Huber Corp. v. Denman, 367 F.2d 104, 112, 120 (5th Cir. 1966); Foremost Int'1 Tours, Inc. v. Qantas Airways Ltd., 379 F. Supp. 88, 95 (D. Hawaii 1974); cf. Association of Data Processing Serv. Organizations, Inc. v. Cainp, 397 U.S. 150, 156 (1970) (doctrine of standing); San Diego Bldg. Trades Council v. Garmon, 359 U.S. 236, 245-46 (1959) (doctrine of preemption); Monsanto Co. v. FPC, 463 F.2d 799, 807 (D.D. Cir. 1972) (doctrine of exhaustion).

25. Atcheson, T. \& S.F. Ry. v. Aircoach Transp. Ass'n, 253 F.2d 877, 886 (D.C. Cir. 1958).

26. Ailes, Some Procedural Problems of Primary Jurisdiction, 13 ABA SEC. ANTITRUST L. 82, 91-93 (1958).

27. United States v. Davidson Transfer \& Storage Co., 302 I.C.C. 87 (1957); United States v. Thoinpson, 299 I.C.C. 477 (1956), rev'd on other grounds, 301 I.C.C. 231 (1957); Continental Charters, Inc., 16 C.A.B. 772 (1953). The technique used to give assistance in Thompson was a declaratory order under section 5(d) of the APA, ch. $324, \S 5,60$ Stat. 239 (1946), as amended 5 U.S.C. $\$ 554(\mathrm{e})(1970)$.

28. Umited States v. Western Pac. R.R., 352 U.S. 59, 70-74 (1956). The Court there said:

The purpose of such statutes [of limitation] is to keep stale litigation out of

the courts. They are aimed at lawsuits, not at the consideration of particular issues in lawsuits. . . . If this litigation is not stale, then no issue in it can be deemed stale. Id. at 72 .

29. The agency may make a determination of liability incidental to granting a remedy other than the one sought by the plamtiff in court. See, e.g., United States v. 
agency's jurisdiction derivative rather than independent. ${ }^{30}$

\section{II}

\section{EXCLUSIVE JURISDICTION OVER THE ISSUE}

Deferral based upon statutory construction has been at the core of traditional primary jurisdiction doctrine. One possible outcome of statutory analysis is a finding of exclusive jurisdiction over the entire controversy. Such a result is not properly one of primary jurisdiction because an essential ingredient-a court's concurrent jurisdiction over the cause of action-is missing. A related concept, referred to in this Comment as "exclusive jurisdiction over the issue," does apply, however, when the subject matter (or remedy) is properly before the court but one or more issues (or elements) within the case are committed by statute to exclusive agency determination, subject to only limited judicial review. This concept fits within primary jurisdiction doctrine because the determination occurs at the preliminary stage of the proceeding and results in a stay or, rarely, in a nonprejudicial dismissal. Use of the exclusive jurisdiction label is appropriate because it makes clear the binding effect and the identity of the analytic process with that developed in exclusive remedy cases. ${ }^{31}$

The traditional doctrine called primary jurisdiction, which in its early years consisted entirely of exclusive jurisdiction ${ }^{32}$ cases, rested upon interests of "uniformity" and "expertise." These policies form part of the motivation for congressional creation of admimistrative agencies. They have, unfortunately, been broadly generalized, and this has interfered with careful examination of primary jurisdiction problems with regard to particular agencies in specific statutory settings. Neither policy should be used merely as a vehicle to accord uncritical deference to agencies or to substitute judicial judgment for that of Congress on the role of regulation in particular industries.

T.I.M.E. Inc., 252 F.2d 178, 181 (5th Cir. 1958), rev'd, 359 U.S. 464 (1959); S.S.W., Inc. v. Air Transp. Ass'n of America, 191 F.2d 658, 662-63 (D.C. Cir. 1951), cert. denied, 343 U.S. 955 (1952).

30. See International Ass'n of Heat \& Frost Insulators v. United Contractors Ass'n, 483 F.2d 384, 404 (3d Cir. 1973) (dictum), modified, 494 F.2d 1353 (3d Cir. 1974).

31. Many of the cases discussed in this section are exclusive remedy cases which may not properly be classified under primary jurisdiction. The theories and concepts developed in thein to support a disnissal apply as well to cases in which only one or two issues, not the entire case, are committed to an agency. The same statutory theory may thereby justify stay of an action.

32. This term when used without further qualification shall refer to exclusive jurisdiction both over the case and over the issue. 


\section{A. Uniformity}

Primary jurisdiction originated in Texas \& Pacific Railway v. Abilene Cotton Oil $\mathrm{Co}^{33}$ in which a shipper brought an action against a railroad based upon a common law claim of charging an unreasonable rate. The Court, per Justice Edward White, held that the plaintiff must "primarily invoke redress through the Interstate Commerce Commission, which body alone is vested with power originally to entertain proceedings." ${ }^{34}$ This holding directly contradicted the statute, ${ }^{35}$ which gave concurrent jurisdiction to the courts and the agency. The conceptual innovation in Abilene was in realizing the potential for sphtting one issue away from the case and sending that issue to the agency. Yet reasonableness of the rate was the only issue in that case, so the result of deferral on that issue was indistinguishable from a finding of exclusive jurisdiction over the entire controversy.

The result in Abilene was based on the theory that the regulatory statute could not work if both the court and the agency could independently decide which rate was reasonable. Since the major purpose of the Interstate Commerce Act was to prevent price discrimination by applying rate schedules evenly to all shippers, there could be only one body with power to set such rates. Otherwise, a shipper could obtain a preferential rate from a generous jury and the lack of uniforumity would subject other shippers to a new form of price discrimination. Congress had designated the ICC as the proper body for deciding the rate question, and court action would be "wholly inconsistent" with such powers. ${ }^{36}$

The policy of unifonmity which Abilene found in the Interstate Commerce Act must be understood precisely. In that regulatory scheme, a uniform published tariff was required which would be "conclusively deemed to be the legal rate." ${ }^{\prime 37}$ There is a particular need for strict uniformity in a rate schedule, however, because any two alternatives are mutually exclusive. In more qualitative areas of regulation, court and agency action may be cumulative or divergent without great harm; hence there is less need in those areas for a single voice, although there should be comity between the two bodies. ${ }^{38}$

33. 204 U.S. 426 (1907).

34. Id. at 448.

35. Interstate Commerce Act, 49 U.S.C. $\$ \$ 9,22$ (1970).

36. 204 U.S. at 441.

37. 49 U.S.C. $\$ 1$ (1970).

38. The broadest version of the uniformity theory has been set forth by Professor Davis:

[A] court should not act upon subject matter that is peculiarly within the agency's specialized field without taking into account what the agency has to offer, for otherwise parties who are subject to the agency's continuous regula- 
An important exception to Abilene's uniformity analysis was developed in Great Northern Railway Co. v. Merchants Elevator Co. ${ }^{30}$ In determining the meaning of terms used in a published railroad tariff, Justice Brandeis leld that, since the interpretation was based upon the ordinary meaning of words and upon undisputed facts, it was a question of law. As such, the issue was appropriate for judicial determination without necessity of referral to the ICC. Uniformity could be secured in this instance by appeal to the Supreme Court.

The "question of law" category established by Merchants has over the years been a common device to avoid deferal. ${ }^{40}$ A more direct tactic lias been to discount an exaggerated version of the uniformity theory. First the rationale is paraphrased to mean avoidance of conflicting opinions of different judges. Then it is held not to warrant deferral because agency interpretations may also be mconsistent, because conflicts among judges will be no more frequent than they were in traditional common law, or because use of the doctrine would not eliminate conflicts since the agency decision would still be reviewable in the courts. ${ }^{41}$ Such reasoning completely misconceives Abilene's policy of judicial non-interference with functions committed by statute to a particular agency and fails to account for distinctions between various statutory policies.

Uniformity was a false doctrinal start. It slould not be retained as a focus of analysis since it brushes too broadly. Abilene should be

tion may become victims of uncoordinated and conflicting requirements.

3 Davis, supra note $1, \S 19.01$ at 5 . Even this version would permit concurrent enforcement in a spirit of cooperation, for example in the field of labor law, except in those rare instances where the orders are directly contradictory. See, e.g., United Brick \& Clay Workers of America v. Deena Artware, Inc., 198 F.2d 637 (6th Cir. 1952); Deena Artware, Inc. v. NLRB, 198 F.2d 645 (6th Cir. 1952) (contradictory findings of fact upheld using the substantial evidence test). It may even be in line with the prophylactic purposes of a statute for one body to punish what the other condones (for example, a certain picketing practice). See Smith v. Evening News Ass'n, 371 U.S. 195, 197-98 (1962).

A case in which the administrative prospective relief (cease and desist order) and judicial retrospective relief (danages) were cumulative is seen in International Longshoremen's Union v. Juneau Spruce Corp., 342 U.S. 237 (1952). Such a cumulation is proper; the court also asserted that it could have given damages even if the NLRB had found no liability. Id. at 244.

39. 259 U.S. 285 (1922).

40. Packard Motor Co. v. NLRB, 330 U.S. 485 (1947); Society of N.Y. Hospitals v. Associated Hosp. Serv., 367 F. Supp. 149, 154 (S.D.N.Y. 1973) (Cost of Living Council); United States v. American Union Transport, Inc., 232 F. Supp. 700, 703-04 (D.N.J. 1964). Contra Southwestern Sugar \& Molasses Co. v. River Terminals Corp., 360 U.S. 411 (1959); Agricultural Transp. Ass'n v. King, 349 F.2d 873, 883-85 (5th Cir. 1965) (emphasizing that policy making and legal interpretation cannot be separated); Louisville \& N.R.R. v. Knox Homes Corp., 343 F.2d 887 (5th Cir. 1965).

41. Deaktor v. L.D. Schreiber \& Co., 479 F.2d 529, 533, 538 n.6 (7th Cir.), rev'd sub nom. Chicago Mercantile Exch. v. Deaktor, 414 U.S. 113 (1973). 
read to hold that the function of the ICC was to achieve a particular kind of regulation (namely, uniform published rates) and that courts cannot interfere in that function. ${ }^{42}$ There is no constant value in uniformity which must be weighed in every primary jurisdiction case, nor does inquiry end if the need for strict uniformity is rejected.

\section{B. Expertise}

Findings of exclusive jurisdiction have also been based upon the need for technical interpretation of agency regulations or industry practices, such as the application of tariffs. ${ }^{43}$ The rationale has been that an agency which inade or approved a controverted rule should know best what the words meant and what to do in situations not clearly covered.

The first leading case to articulate technical complexity as a distinct policy behind deferral was Merchants. ${ }^{44}$ At issue was whether a reconsignment order was a "disposition order" within the meaning of a tariff exception. In Merchants, Justice Brandeis developed the important theoretical distinctions between administrative and judicial functions which should be at the core of primary jurisdiction analysis. Determination of a reasonable rate for the future is an administrative or legislative function; determination of past wrongs is a judicial function. ${ }^{45}$ Yet both require preliminary deferral:

because the inquiry is essentially one of fact and of discretion in technical nuatters; and uniformity can be secured only if the determination is left to the Commission. Moreover, that determination is reached ordinarily upon voluminous and conflicting evidence, for the adequate appreciation of which acquaintance with many intricate facts of trausportation is indispensable; and such acquaintance is commonly to be found only in a body of experts. ${ }^{46}$

Preliminary determination by an agency would thus be needed only where the words to be interpreted have a peculiar, technical or local meaning, the construction of which requires extrinsic evidence and ex-

42. JAFFE, supra note 1, at 125; Convisser, supra note 1, at 336.

43. Lichten v. Eastern Airlines, Inc., 189 F.2d 939 (2d Cir. 1951).

44. Great N. Ry. v. Merchants Elevator Co., 259 U.S. 285 (1922). See text accompanymg note 39 supra. The first case to recognize expertise as a basis for the doctrine was Mitchell Coal and Coke Co. v. Pennsylvania R.R., 230 U.S. 247 (1912).

45. 259 U.S. at 291.

46. Id. For an excellent survey of Justice Brandeis' lifelong efforts to define the boundaries of administrative law doctrines, including primary jurisdiction, see White, $A l$ locating Power Between Agencies and Courts: The Legacy of Justice Brandeis, 1974 DUKE L.J. 195. 
perience in the industry. ${ }^{47}$ The Court ultimately held that the term "disposition order" was used in its ordinary sense and affirmed the lower court's decision on its meaning. ${ }^{48}$

A second leading case on technical construction was United States v. Western Pacific Railroad Co. ${ }^{49}$ At issue was whether a napalin gel with a casing but without a fuse was an "incendiary bomb" as that term was used in a tariff. The Supreme Court found that the ICC had exclusive jurisdiction. Construction of the tariff, said Justice Harlan, required an inquiry into transportation policy, cost analysis, safety, fair return, insurance, and "commercial reasons" for the tariff and was inseparable from the issue of the basic reasonableness of the tariff as applied. ${ }^{50}$ In sum, the ICC originally determined the rate, and court interpretation would be "judicial guesswork." "51

Properly viewed, cases like Western Pacific hold not that agency expertise is crucial, but rather that Congress lias vested an agency with broad powers which mandate deferral to agency findings on the application of agency-promulgated rules. Whether or not it was truly expert, the ICC had statutory power; another agency or a court might be as competent in the area in question but not have similar statutory power. ${ }^{52}$

47. Justice Brandeis distinguished Texas \& Pac. Ry. v. American Tie \& Timber Co., 234 U.S. 138 (1914), in which Justice White held that the ICC must determine whether the term "Iumber" included railroad ties, saying that the disputc there was over the factual question of usage of the words. This distinction is untenable, because every question of meaning can be rephrased as a question of fact. Tie called the clear meaning rule a "palpable error of law." Id. at 147.

48. 259 U.S. at $294-96$. terms:

49. 352 U.S. 59 (1956). The court summarized the doctrine in the following

The doctrine of primary jurisdiction, like the rule requiring exhaustion of administrative remedies, is concerned with promoting proper relationships between the courts and administrative agencies charged with particular regulatory duties. . . [ [t] applies where a claim is originally cognizable in the courts, and comes into play whenever enforcement of the claim requires the resolution of issues which, under a regulatory scheme, have been placed within the special competence of an administrative body; . . .

No fixed formula exists for applying the doctrine of prinary jurisdiction. In every case the question is whether the reasons for the existence of the doctrine are present and whether the purposes it serves will be aided by its application in the particular litigation.

Id. at 63-64. This case is noted at 71 HARv. L. Rev. 163 (1957); 55 Mich. L. Rev. 864 (1957).

50. 352 U.S. at $66-68$.

51. Id. at 68. The impact of this case is muted by the subsequent action of the ICC, which came to the same conclusion as the Court of Claims: the gel was a bomb. 309 I.C.C. 249, 262 (1959); 131 F. Supp. 919 (Ct. Cl. 1955).

52. See MCI Communications Corp. v. American Tel. \& Tel. Co., 496 F.2d 214, 223 (3d Cir. 1974) (FCC); Locust Cartage Co. v. Transamerican Freight Lines, Inc., 430 F.2d 334, 339-40 (1st Cir.), cert. denied, 400 U.S. 964 (1970) (ICC); Agricultural Transp. Ass'n of Texas v. King, 349 F.2d 873, 883-85 (5th Cir. 1965) (ICC). 
These principles are reflected in the application of primary jurisdiction to the Federal Maritime Commission (FMC). In Port of Boston Marine Terminal Association v. Rederiaktiebolaget Transatlantic, $^{63}$ the issue was whether a shift of a tariff charge was a "modification" requiring prior FMC approval under the provisions of the Shipping Act. ${ }^{54}$ The agency ruled that it was not, because the cliarge was within the scope of a previously approved agreement. The Supreme Court held that the district court would "lack the requisite capacity" to decide the issue; this usage should be understood to refer not to the technical complexity but to jurisdiction over agreements which the FMC had already approved. ${ }^{55}$ The case does not rest on abstract expertise but upon upholding the allocation of power made by the statute.

Two earher antitrust cases relating to the shipping industry, however, had elaborated the expertise theory in terms which tend to direct attention away from reliance on statutory allocation of roles. United States Navigation Co. v. Cunard S.S. Co. ${ }^{56}$ held that only the agency, then called the Federal Maritime Board (FMB), could determine certain violations of the Shipping Act. ${ }^{57}$ The decision rested very heavily upon the technical expertise of the FMB and thereby gave an expansive reading to an express provision of the Act which allowed restrictions on competition for the health of the industry. ${ }^{58}$ In Far East Confer-

53. 400 U.S. 62 (1970).

54. 46 U.S.C. $\S \S 800-42$ (1970).

55. 400 U.S. at 69. Cf. Tampa Phosphate R.R. v. Seaboard Coast Line R.R., 418 F.2d 387, 402 (5th Cir. 1969), where the concurring judge stated that "[t]he district court is not the place to thresh this issue out" in light of a statutory provision (49 U.S.C. $\S 1(18)(1970)$ ).

56. 284 U.S. 474 (1932). A carrier sought an injunction under the antitrust laws against a dual-rate system, wherein a discount rate was given to shippers who agreed to use the facilities of conference (cartel) memners exclusively. This rate system had not been specifically approved by the Federal Maritime Board but had been set up under an approved conference agreeinent.

57. 284 U.S. at 485 . The reasoning of Cunard, that even failure to file does not bar FMB jurisdiction, is based upon an exclusive remedy theory from sections 22 and 31 of the Act, 46 U.S.C. $\S \S 821,830$ (1970). An important aspect of this theory is that the pleadings cannot remove jurisdiction simply by characterizing the conduct as a violation of the Sherman Act instead of the Shipping Act. 284 U.S. at 485.

58. Shipping Act $\S 15,46$ U.S.C. $\$ 814$ (1970). The inost relevant portion of section 15 stated:

The board may by order disapprove, cancel, or modify any agreement . . . that it finds to be unjustly discriminatory or unfair ... or to operate to the detriment of the commerce of the United States, or to be in violation of this Act, and shall approve all other agreements, modifications, or cancellations. . . .

[B]efore approval or after disapproval it shall be unlawful to carry out . . . any such agreement, modification, or cancellation.

Every agreement, modification, or cancellation lawful under this section shall be excepted from the provisions of the [Sherman Act].

The court elaborated these powers:

The [Shipping] act is restrictive in its operation upon some of the activities of common carriers by water, and permissive in respect of others. Their 
ence v. United States, ${ }^{59}$ Justice Frankfurter followed Cunard and supplied the classic statement of an extreme pro-agency view of exclusive jurisdiction:

The [Cunard] Court thus applied a principle, now firmly established, that in cases raising issues of fact not within the conventional experience of judges or cases requiring the exercise of administrative discretion, agencies created by Congress for regulating the subject matter should not be passed over. This is so even though the facts after they have been appraised by specialized competence serve as a premise for legal consequences to be judicially defined. Uniformity and consistency in the regulation of business entrusted to a particular agency are secured, and the limited functions of review by the judiciary are nore rationally exercised, by preliminary resort for ascertaining and interpreting the circumstances underlying the legal issucs to agencies that are better equipped than courts by specialization, by insight gained through experience, and by nore flexible procedure. 0

Such vague language glosses over the very limited nature of the statutory power upon which the FMB's authority rested, although the result was justified because the relief sought (an injunction) did fall within the scope of the exemption. ${ }^{\text {II }}$ The Far East restatement also provides very little guidance in distinguishing close cases, thus inviting decisions based upon intuitive assessment by a judge that facts either are or are not sufficiently specialized.

Grounding exclusive jurisdiction upon expertise in the abstract provides a convenient opportumity for courts which wish to belittle the the need for deferral. The policy is described as requiring deferral "on account of the difficult questions involved, which may require ex-

business involves questions of an exceptional character, the solution of which may call for the exercise of a high degree of expert and technical knowledge. Whether a given agreement among such carriers should be held to contravene the act may depend upon a consideration of economic relations, of facts peculiar to the business or its history, of competitive conditions in respect of the shipping of foreign countries, and of other relevant circumstances, generally unfamiliar to a judicial tribunal, but well understood by an administrative body especially trained and experienced in the intricate and technical facts and usages of the shipping trade; and with which that body, consequently, is better able to deal. ..."

284 U.S. 474, 485 (1932).

59. 342 U.S. 570 (1952). The facts were similar to Cunard, except that the suit was brought by the Justice Department. The case was decided simply on precedent: "The same considerations of administrative expertise apply, whoever initiates the action." Id. at 576. The FMB intervened in the case in favor of upholding the existing system. This case is noted at 66 Harv. L. REv. 89, 158 (1952); 28 IND. L.J. 194 (1953); 101 U. PA. L. REv. 678 (1953).

60. 342 U.S. at 574-75.

61. See text of section 15 of the Shipping Act at note 58 supra. Justice Douglas dissented, arguing that the exemption was only available through filing in advance of implementation. 342 U.S. at 577-79. 
pertise beyond that of the average judge or juror." ${ }^{2}$ This version of the expertise analysis is easily negated by statements that the facts are not very complicated and that expertise is overrated anyway. ${ }^{63}$ This is a parody of the doctrine, which is based on respect for statutory delegation of certain functions to administrative agencies.

\section{Statutory Construction}

A finding of exclusive jurisdiction is a conclusion of law. Even where a statute expressly creates such authority in an agency, it remains for the courts to define the scope of such power. In borderline cases there is an opportunity for a court to apply its own policy preferences. A rigorous niethodology of statutory construction is needed to keep this from becoming a wholly discretionary process. ${ }^{64}$ Unfortunately, many cases reveal the bias of a court for or against administrative agencies or conrpetition in general, with dogmatic language used to justify a preconceived result. ${ }^{65}$

Statutory analysis requires a definition of the particular issue in dispute (e.g., the defendant's conduct), followed by an analysis of the agency's function and power with respect to that issue. The court can determine the statutory power question at once if exclusive jurisdiction exists in one of its three principal neeanings: (1) the issue concerns the scope of a rule or agreenient already approved by the agency, (2)

62. Deaktor v. L.D. Schreiber \& Co., 479 F.2d 529, 533 (7th Cir.), rev'd sub nom. Chicago Mercantile Exch. v. Deaktor, 414 U.S. 113 (1973). See also International Bhd. of Boilermakers v. Hardeman, 401 U.S. 233, 238-40 (1971); Crain v. Blue Grass Stockyards Co., 399 F.2d 868, 874 (6th Cir. 1968); Pennsylvamia R.R. v. Fox \& London, 93 F.2d 669 (2d Cir. 1938).

63. Cases in which the courts have decided extremely technical questions are perhaps useful antidotes to cases exaggerating the factual complexity of certain issues. See, e.g., Brown Lumber Co. v. Louisville \& N.R.R., 299 U.S. 393 (1937) (Brandeis, J.); Texas \& Pac. Ry. v. Gulf, C. \& S.F. Ry., 270 U.S. 266 (1926) (Brandeis, J.); Burris Mill \& Elevator Co. v. Chicago R.I. \& Pac. R.R, 131 F.2d 532 (10th Cir. 1942); American Ry. Express Co. v. Price Bros., Inc., 54 F.2d 67 (5th Cir. 1931); Louisville \& N.R.R. v. United States, 106 F. Supp. 999 (W.D. Ky. 1952).

64. Sources emphasizing statutory construction or statutory accommodation are: JAFFe, supra note 1, at 124; Convisser, supra note 1, at 315; Mitchell, Primary Jurisdiction-What It Is and What It Is Not, 13 ABA SEC. ANTrTRUST L. 26, 35 (1958).

65. Cases dealing with the jurisdiction of the $C A B$ provide examples of the inconsistency which can result from a statutory construction guideline. Compare S.S.W., Inc. v. Air Transp. Ass'n of America, 191 F.2d 658 (D.C. Cir. 1951), cert. denied, 343 U.S. 955 (1952) (conspiracy to injure; the board could issue a cease and desist order, while the court retained jurisdiction to award damages); and Apgar Travel Agency v. International Air Transp. Ass'n, 107 F. Supp. 706 (S.D.N.Y. 1952) (sane conspiracy), with Shick Airways v. American Airlines, 107 F. Supp. 199 (D.N.J. 1951), appeal dismissed, 204 F.2d 230 (3d Cir.), cert. denied, 346 U.S. 806 (1953) (conspiracy to injure a coinpetitor). These differences persist despite the fact that all of the cases alleged very unusual forms of competition, over which the CAB's power of approval may be doubted. 49 U.S.C. $\$ \S 491,494$ (1970). 
the issue could be decided pursuant to an express agency power, or (3) the issue could be decided pursuant to an implied power. ${ }^{00}$ If the statutory language or the factual record is not clear enough to allow one of these conclusions with a high degree of: certainty, then options of deferral whicli carry uncertain binding effect nnay be utilized.

Because this analytical inethod involves statutory construction, it is appropriate that the applicable precedents be grouped according to the regulatory act and agency in question. General values of uniformity and expertise must be given concrete content by reference to the particular statutory contexts in which they arise. Nevertheless, as this Comment lopes to make clear, there is an overriding theoretical structure which links the cases and illuminates parallel developments under different acts.

\section{III}

\section{"ARguably LaWful" Conduct}

The rationales of Cunard and Far East proved too extreme to serve as final interpretations of primary jurisdiction under the Shipping Act because they implied that deferral to the FMB ineant that courts would be bound by agency action. ${ }^{67}$ In two later antitrust cases this approach was modified to take account of the precise terms of the express exemption in the Shipping Act. Federal Maritime Board v. Isbrandtsen $\mathrm{Co}^{68}$ held that the agency approval was subject to reversal by the courts using their power to decide questions of law. Carnation Co. v. Pacific Westbound Conference ${ }^{69}$ held that the FMC had the

66. Cf. King, The "Arguably Lawful" Test of Primary Jurisdiction in Antitrust Litigation Involving Regulated Industries, 40 TENN. L. REv. 617, 631 (1973).

This same structure of analysis is used even if the case does not involve antitrust issues. District Council v. Seatrain Lines, Inc., 377 F. Supp. 1278 (E.D. Pa. 1973) (applying the same type of analysis to violation and antitrust claims).

Professor Jaffe would use as a guideline for statutory interpretation the standard of "what is necessary to make all the prescribed procedures workable." JAFFe, supra note 1, at 124. This he holds to be true whether or not there is an express exemption; for instance, the theoretical technique of focusing upon the scope or reach of the single regulatory act, as opposed to "reconciling" that act with the antitrust laws, is thus the same for all regulatory schemes.

67. Far East Conf. v. United States, 342 U.S. 570 (1952); United States Navigation Co. v. Cunard S.S. Co., 284 U.S. 474 (1932).

Application of the expertise rationale of Far East without regard to the particular facts of the case was illustrated in United States v. Alaska S.S. Co., 110 F. Supp. 104, 111 (W.D. Wasl. 1952). The complaint charged threats against competitors, in the form of discriminatory rates and service, and inducements to other carriers not to aid the plaintiff carriers. Such conduct is clearly distinguishable from the structural system of Far East, using the "arguably lawful" approach to statutory construction.

68. 356 U.S. 481 (1958).

69. 383 U.S. 213, modified, 383 U.S. 932 (1966). 
power to approve agreements prospectively only, not to validate prior unapproved agreements.

The result of these and other cases was a hybrid ground of deferral in time, partly statutory and partly discretionary, which utilized an initial procedural test of whether the challenged conduct was "arguably lawful" under a regulatory scheme. If the test is met, the case is deferred to the agency. The "lawful" criterion is satisfied if exclusive jurisdiction (in one of the three meanings) might be the ultimate outcome of the case. The "arguable" criterion is satisfied by a reasonable probability that such lawful attributes will be established at the time of eventual judicial review of the agency's action. Even if the court cannot foresee that such a result is certain, there may be sound reasons to defer.

This theory allows primary jurisdiction (deferral in time) without a prior commitment as to scope of review. As such it is an appropriate and useful tool for judicial supervision of moderately-regulated industries and for cases in which the statutory command is unclear or the application of the statute depends upon particular facts. The analysis can be applied to a spectrum of cases ranging from those where exclusive jurisdiction is almost certain to those where deferral is probably not commanded by statute. Towards one end of this spectrum, deferral is based upon the "risk of interference" with a comprehensive scheme of regulation, an idea which is a diluted variant of the uniformity norm. At the other end, deferral is grounded on the utility of receiving an agency's view of its own power and the facts of the case. This rationale is a variant of the expertise norm, in which agency action is "preparing the way" for the court's eventual decision of the case.

\section{A. Risk of Interference}

Carnation involved a shipper who sought to recover treble damages against two conferences of shipping compamies which had implemented unapproved rateinaking agreements, allegedly restraining competition. $^{70}$ Recognizing a limited antitrust exemption for such agreeinents which could be obtained by prior FMC approval, ${ }^{71}$ the Court found no statutory support for exemption of unapproved agreements from the antitrust laws. Cunard and Far East were reviewed, with emphasis upon the iniportance of avoiding conflict between the courts and the agency, ${ }^{72}$ but the Court concluded that

70. Id.

71. Id. at 216-17.

72. [C]ourts must refrain from imposing antitrust sanctions for activities of debatable legality under the Shipping Act in order to avoid the possibility of conflict between the courts and the Commission. 
[t]he Far East and Cunard principles permit courts to subject activities which are clearly unlawful under the Shipping Act to antitrust sanctions so long as the courts refrain from taking aotion which might interfere with the Commission's exercise of its lawful powers. ${ }^{73}$

The district court was ordered to stay the case pending the outcome of agency proceedings on whether the conduct was an implementation of another previously approved agreement. ${ }^{74}$

The Carnation solution is supported by a careful reading of the exemption section. The Shipping Act gives the agency an express power to immunize agreements from antitrust sanctions, yet the extent of the power cannot be determined before the facts of each case are developed. Deferral allows both protection of the statutory power of prospective approval and enforcennent of the prescribed procedure for obtaining an exemption. In Carnation, there existed an arguable version of the facts and law such that a rational body could decide in favor of the defendants. ${ }^{75}$ There was a risk of prejudicing the FMC's proceedings even if the court decided only questions relating to past conduct and damages. The only practical way to coordmate such a mixed case was to let the agency proceed first.

Where there is an express agency power to give antitrust immunity, as in the Shipping Act cases, risk of interference is clear and the "arguably lawful" test for deferral will generally be satisfied, at least as to future conduct. ${ }^{76}$ Even where there is no express provision, a rea-

... [T]he danger of such a conflict could best be avoided by holding that one tribunal or the other has the exclusive right to make the initial factual determination.

383 U.S. at 220.

73. Id. at 221.

74. Id. at 224. The FMC had already decided that the subsequent rate increases were not within the scope of the consultation agreements approved in 1952. An appeal from that decision was pending at the time the Supreme Court handed down its opinion. Id. at 223 \& n.6.

75. Both the district court and the court of appeals had dismissed the action because the FMC could have decided that the activities were an implementation of a prior approved agreement. Carnation Co. v. Pacific Westbound Conf., 336 F.2d 650 (9th Cir. 1964).

76. For further cases involving the Shipping Act, see Maddock \& Miller, Inc. v. United States Lines, 365 F.2d 98, 102 (2d Cir. 1966); Sabre Shipping Corp. v. American President Lines, Ltd., 285 F. Supp. 949 (S.D.N.Y. 1968), affd, 407 F.2d 173 (2d Cir.), cert denied, 395 U.S. 922 (1969).

In applying the "arguably lawful" test to the powers of the CAB, the views of courts have conflicted. Compare Price v. Trans World Airlines, Inc., 481 F.2d 844 (9th Cir. 1973) (alleged discrimination in charges for headsets); Laveson v. Trans World Airlines, 471 F.2d 76 (3d Cir. 1972) (same facts as in Price); Lichten v. Eastern Airlines, Inc., 189 F.2d 939, 941 (2d Cir. 1951); and Executive Airlines, Inc. v. Air New England, Inc., 357 F. Supp. 345 (D. Mass. 1973), with Breen Air Freight, Ltd. v. Air Cargo, Inc., 470 F.2d 767 (2d Cir. 1972), cert. denied, 411 U.S. 932 (1973); Allied Air Freight, Inc. v. Pan Am. World Airways, Inc., 393 F.2d 441 (2d Cir.), cert. denied, 
sonable argument can often be made that a regulatory statute creates a comprehensive scheme and that court resolution of certain substantive issues would constitute interference with the agency's administration of that scheme. ${ }^{77}$ In determining whether agency immunization is an arguable issue, of course, pleadings should not be accepted at face value; rather, underlying facts should be examined in light of the agency's normal function. ${ }^{78}$

\section{B. Factual Preparation}

The analysis and result in Carnation represented a more careful application of the express exemption than the earlier decision in Isbrandtsen.$^{70}$ In Isbrandtsen, a dual-rate agreement similar to that litigated in Far East was approved by the FMB. The issue was the iminunization effect of such approval, not deferral. The Court, using its power to construe what a "Iawful" agreement was, held that the agreeinent had an anticompetitive purpose and was thus illegal per $s e .{ }^{80}$

393 U.S. 846 (1968) (conspiracy resulting in bankruptcy of the plaintiff, not arguably lawful; no effect on future conduct); Trans World Airlines, Inc., v. Hughes, 332 F.2d 602 (2d Cir. 1964), rev'd, 409 U.S. 363 (1973); and Aloha Airlines, Inc. v. Hawaiiań Airlines, Inc., 349 F. Supp. 1064 (D. Hawaii 1972), aff'd, 489 F.2d 203 (9th Cir. 1973), cert. denied, 417 U.S. 913 (1974).

77. The evils of sporadic interference with a "delicate regulatory scheine" weré noted but not found in Mercury Motor Express, Inc. v. Brinke, 475 F.2d 1086, 1092 94 (5th Cir. 1973). The notion of self-imposed restraint was stressed in Ashland Oil \& Ref. Co. v. FPC, 421 F.2d 17, 20 (6th Cir. 1970).

78. United States v. Western Pac. R.R., 352 U.S. 59, 69 (1956). The Court said: "To hold otherwise would make the doctrine of primary jurisdiction an abstraction tô be called into operation at the whim of the pleader." Obviously the arguinent that "conspiracy" cannot be "arguably lawful" is an abuse of the doctrine. Cf. Seatrain Lines, Inc. v. Pennsylvania Ry., 207 F.2d 255, 261 (3d Cir. 1953). Although the allegations of fact must generally be accepted as true in ruling on a motion to disiniss, FED. $R$. Crv. P. 12(b), 56, this rule cannot apply to a primary jurisdiction ruling because of the statutory respect and technical matters policies behind the doctrine. Carter v. American Tel. \& Tel. Co., 365 F.2d 486, (5th Cir. 1966), cert. denied, 385 U.S. 1008 (1967). The allegatious can still be accepted in ruling on whether a cause of action is stated. Israel v. Baxter Laboratories, Inc., 466 F.2d 272, 279 (D.C. Cir. 1972).

In Palenno v. Bell Tel. Co., 415 F.2d 298, 300 n.4 (3d Cir. 1969), the plaintiffs tried to avoid the primary jurisdiction doctrine by not challenging the reasonableness of the tariff which had been set, but had their complaint dismissed for failure to state a cause of action.

79. 356 U.S. 481 (1958). See also Auerbach, The Isbrandtsen Case and Its Aftermath, 1959 WIs. L. Rev. 223, 369; Note, The Isbrandtsen Decision: Anti-trust Laws, Regulated Industries and the Doctrine of Primary Jurisdiction, 53 Nw. U.L. REv. 803 (1959); Comment, Freight Fonvarders, Brokerage, and Shipping Conference Agreements: Implications of the Isbrandtsen Doctrine, 27 U. CHI. L. REv. 777 (1960).

80. The FMB approved the dual rate system and a spread of $9.5 \%$ between contract and non-contract rates. 4 F.M.B. 706 (1955). It found that the system was neither "unjustly discriminatory" nor in retaliation, so that section 812 Third was not violated. 4 F.M.B. at 734-38. The section forbids any carrier to "[r]etaliate against any shipper . . . or resort to other discriminatory or unfair methods ...." 46 U.S.C. \$ 
Justice Frankfurter, author of the Far East opinion, dissented, arguing that finding the dual-rate system illegal per se was inconsistent with Cunard and Far East. ${ }^{81}$ His understanding was that a holding of primary agency jurisdiction had the binding effect of exclusive jurisdiction. The Isbrandtsen majority's reading of the Act on this point is doctrinally more sound. Since in some situations it would be proper for a court to declare a dual-rate system illegal without resort to the agency, exclusive agency jurisdiction did not lie. The validity of Cunard and Far East depended upon reserving to the FMB the power to confer prospective immunity, not upon granting it the exclusive right to decide the question of illegality.

The holding in the case did, however, reveal an unwarranted intrusion upon the FMB's statutory power to prospectively immunize agreements. $^{82}$ As a justification for its reversal of the agency decision, the majority added some widely-quoted dicta to the effect that the agency record was inerely preparatory to the later court case:

[I]n certain kinds of litigation practical considerations dictate a division of functions between court and agency under which the latter makes a preliminary, comprehensive investigation of all the facts, analyzes them, and applies them to the statutory sclieme as it is construed. It is recognized that the courts, while retaining the final authority to expound the statute, should avail themselves of the aid implicit in the agency's superiority in gathering the relevant facts and in marshaling them into a meaningful pattern. Cases are not decided, nor the law appropriately understood, apart from an informed and particularized insight into the factual circumstances of the controversy under litigation.

... The lrolding that the Board had priniary jurisdiction, in short, was a device to prepare the way, if the litigation should take its ultimate course, for a more informed and precise determination by the Court of the scope and meaning of the statute as applied to

812 Third (1970). The Court converted the FMB's finding that the system was de: signed to "meet . . . competition," 4 F.M.B. at 739 , into a finding that the system was for the purpose of "curtailing . . . competition," 356 .U.S. at 500. The system was thus a "predatory device" in violation of the above section. Id. at 499 .

81. 356 U.S. at 517-19.

82. The language of the section did not say that the FMB could approve "lawful" agreements, but that agreements approved by the board were to be lawful. 46 U.S.C. $\$ 814$ (1970). Even if section 812 Third, which prohibited predatory practices, was properly construed as a limit upon the power of approval, the Court's twisting of the FMB's fact-finding, see note 80 supra, was unwarranted.

Section 812 Third was amended by the Act of Aug. 12, 1958, Pub. L. No. 85-626, 72 Stat. 574, to temporarily overrule Isbrandisen for two years while Congress pondered the problem. Subsequently, retroactive approval was allowed by the statute with certain restrictions. Act of Oct. 3, 1961, Pub. L. No. $87-346, \S 1$, 75 Stat. 762,46 U.S.C. $\S$ 813a (1970). 
those particular circumstances. To have held otherwise would, necessarily, involve the Court in coinparatively abstract exposition. ${ }^{83}$

These concepts do not apply, of course, to cases of true exclusive jurisdiction. Deferral reserving to the court power over the substantive question was not appropriate in light of the express power of the FMB to approve agreements for the future.

Although this theory was misapplied to the facts in Isbrandtsen, it is a useful tool for dealing with cases in which exclusive agency jurisdiction is only remotely possible. So long as there is an "arguably lawful" version of the defendant's conduct, prior agency factfinding may provide certain benefits to a court's ultimate decision regarding the scope of agency powers. ${ }^{84}$ For example, in Isbrandtsen the Court purported to use a single factual finding by the FMB to greatly simplify its analysis. This rationale--justifying deferral upon factors of judicial administration-serves as a basis for the material aid approach discussed in the next part.

\section{IV \\ Material Aid \\ A. Emergence of $A$ New Theory}

Although there had been numerous lower court statements to the effect that deferral could be discretionary and advisory, ${ }^{85}$ before 1973 the Supreme Court had never employed primary jurisdiction principles to require judicial deferral to agency findings while simultaneously holding that those findings would not be binding. ${ }^{86}$ Yet sucl an ap-

83. 356 U.S. at $498-99$ (citation omitted).

84. The Far East case, as interpreted in Isbrandtsen, is the principal authority for the view that the agency's preliminary view may also be sought for a question of statutory construction, even though the courts will make the final interpretation. This is based upon the maxim that the agency's view of its own authorizing statute is entitled to "great weight" because of its daily contact with the need to make the statute workable. United States v. American Trucking Ass'ns, 310 U.S. 534, 549 (1940). This technique was even used in a case where there was no express authority for the agency decision to create immunity. Atchison, T. \& S.F. Ry. v. Aircoach Transp. Ass'n, 253 F.2d 877, 883 (D.C. Cir. 1958), cert. denied, 361 U.S. 930 (1960).

85. See, e.g., Wheelabrator Corp. v. Chafee, 455 F.2d 1306, 1316 (D.C. Cir. 1971); J.M. Huber Corp. v. Denman, 367 F.2d 104, 111 (5th Cir. 1966); Trans World Airlines, Inc. v. Hughes, 332 F.2d 602, 609 (2d Cir. 1964); Atchison, T. \& S.F. Ry. v. Aircoach Transp. Ass'n, 253 F.2d 877, 885 (D.C. Cir. 1958). There have been equally strong assertions in the cases that the doctrine is not discretionary or merely "advisory." See Locust Cartage Co. v. Transamerican Freight Lines, Inc., 430 F.2d 334, 339-41 (1st Cir. 1970); Elgin, J. \& E. Ry. v. Benjamin Harris \& Co., 245 F. Supp. 467, 469 (N.D. III. 1965).

86. There had been dicta in earher cases, all of which actually rested on a statutory theory. See, e.g., Montana-Dakota Util. Co. v. Northwestern Pub. Serv. Co., 341 U.S. 246, 254 (1951); Thompson v. Texas-Mexican Ry., 328 U.S. 134, 151 (1946); Order of Ry. Conductors of America v. Pitney, 326 U.S. 561, 566-67 (1946). 
proach is appropriate for regulatory schemes which rely largely upon self-regulation by the private sector and where the powers of a regulatory agency may be limited or uncertain. Ricci v. Chicago Mercantile Exchange $e^{87}$ involved a statute which on its face required neither deferral to agency action nor its subsequent binding effect. ${ }^{88}$ Nonetheless, the Court construed the statute to grant concurrent agency jurisdiction in the form of a hearing procedure and then based deferral upon discretionary factors of judicial convenience.

Ricci centered on a claim that the exchange and one of its members had used a blank authorization form signed by the plaintiff to transfer his exchange nembership to a third person. ${ }^{89}$ It was alleged that the transfer was niade pursuant to a conspiracy to restrain competition, in violation of section 1 of the Sherman Act, ${ }^{00}$ the Commodity Exchange $A c t^{01}$ and the rules of the exchange. ${ }^{22}$ The defendants claimed that the rules allowed such a transfer and that comphance with

87. 409 U.S. 289 (1973). Justice White wrote the Court's opinion, in which Chief Justice Burger and Justices Brennan, Blackmun and Rehnquist joined. The Chief Justice wrote a separate concurring opinion. Justice Marshall dissented, joined by Justices Douglas, Stewart and Powell. Justice Douglas also wrote a short dissenting opinion. For discussion of this case, see King, The "Arguably Lawful" Test of Primary Jurisdiction in Antitrust Litigation Involving Regulated Industries, 40 TENN. L. REv. 617, 651-55 (1973); Comment, New Twists on Old Wrinkles: Primary Jurisdiction and Regulatory Accommodation with the Antitrust Laws, 15 B.C. IND. \& CoM. L. REv. 80, 96-105 (1973); Note, Primary Jurisdiction in Antitrust Cases: Three Recent Decisions, 42 U. Cinn. L. Rev. 725, 730-34 (1973). See also Miron, Primary Jurisdiction, 43 ANTITRUST L.J. 329, 345-46 (1974).

88. Commodity Exchange Act, 7 U.S.C. $\$ \$ 1-17 b$ (1970). See note 91 infra.

89. Some facts not available from the court opinions are that (1) Ricci was an employee of the defendant Siegel Trading Company and was only 20 years old when one of the company's memberships was first placed in his name; (2) the authorization form was routinely used by exchange members to retain control of such memberships; and (3) the dispute arose over who was entitled to the $\$ 30,000$ increase in value of a seat which was originally priced at about $\$ 15,000$. Workshop I: Regulated Industries, 43 ANTitrust L.J. 125, 142-43 (1970) (remarks of Mr. Jerrold E. Salzman). The plaintiff purchased a new seat about a month after the old one was transferred. 409 U.S. at 291. On the basis of such facts, admitted by the plaintiff, it is difficult to seo how a boycott or conspiracy charge could be pressed so far.

90. 15 U.S.C. $\$ 1(1970)$.

91. 7 U.S.C. $\$ \S 1-17 b(1970)$. The Act established the Commodity Exchange Commission, Composed of the Secretaries of Agriculture and Commerce and the Attorney General, to regulate trading in certain agricultural commodity futures. The Commission had jurisdiction to discipline an exchange for violation of the Act or rules, $i d$. $\S 8$, while the Secretary of Agriculture had jurisdiction to discipline futures commission merchants and floor traders, id. $\S 9$, and to disapprove any rule of the exchange relating to contracts or "other trading requirements," $i d$. \& 12a(7). The Act was substantially revised by the Commodity Futures Trading Commission Act of 1974, Pub. L. No. 93463, 88 Stat. 1389 (Oct. 23, 1974).

92. Applicable rules of the CME were number 307 (relating to sale of a membership) and number 322 (concerning qualification to trade). 409 U.S. at 299 n.11. Neither of these rules deals specifically with the question of holding a membership in the name of another person. 
them constituted a defense to the antitrust charge. The Court refrained from any decision on the immunity question. It held that the Commodity Exchange Commission should have primary jurisdiction because three conditions were assumed to be present: (1) immunity was a possible consequence of the regulatory scheme; (2) some facets of the case were arguably within the statutory jurisdiction of the Commission; and (3) prior adjudication by the Commission (of the question of whether the rules were followed) promised to be of "material aid" to the court in resolving the immunity question. ${ }^{93}$

The majority opinion in Ricci started from the generalization that certain restraints on competition were inherent in the exchange system and were approved by the Commodity Exchange Act (CEA), so that conduct im accordance with those restraints was arguably lawful. ${ }^{94}$ The term "lawful" here means "approvable in the court's ultimate reading of the statute," a usage which should be distinguished from the potential agency power of approval under an express statutory immunity provision, such as the one applicable in Carnation and Isbrandtsen. ${ }^{95}$

There are three distinct ways in which the defendant's alleged conduct in Ricci might be found unlawful. The exchange rule itself might be invalid as an unjustified restraint on competition, the rule may have been comphed with but in a specifically anti-competitive manner, or the defendants may simply have violated the rule. If the third possibility were emphasized, deferral in Ricci could be seen to be based upon exclusive agency jurisdiction over the issue of violation of the CEA and the rules. ${ }^{96}$ If so, the case would fit into traditional analysis,

93. Id. at 302 .

94. The Court did not use this term, stating that the issue of whether the rule was "incompatible" with an antitrust action "has substance." Id. at 302-03. This usage follows that of Silver v. New York Stock Exchange, 373 U.S. 341, 358, 360 (1963), cited by the Court in Ricci to support the first point of its test. Silver and its progeny created a body of law on the merits of immunity in the self-regulated areas which preceded Ricci, but none of those cases dealt directly with the primary jurisdiction issue.

The question of immunity was open because "[t]he Act clearly contemplates a membership organization." 409 U.S. at 303. An implicit recognition of limited membership policies and rate fixing is the provision of 7 U.S.C. $\$ 7$ (e) (1970) that an exchange may not exclude a cooperative association from membership and must allow cooperative members to receive patronage rebates in order to avoid rate fixing. See Chicago Bd. of Trade v. Olsen, 262 U.S. 1, 7, 40-42 (1923).

95. Carnation Co. v. Pacific Westbound Conf., 383 U.S. 213, modified, 383 U.S. 932 (1966); Federal Maritime Bd. v. Isbrandtsen Co., 356 U.S. 481 (1958).

96. The theory of United States v. Western Pacific R.R., 352 U.S. 59 (1956) would have to be stretched to cover this case, for the facts are not very intricate and do not go to the economic basis of the rules in question. On the other hand, since the rules are vague expertise would be beneficial in their interpretation.

There might also be a risk of interference rationale for deferral here, but the opinion does not pursue that line. The Commission has discretion not to prosecute minor 
and "material aid" regarding the other two issues would simply be a bonus for the court.

The importance of the material aid concept in the Court's analysis and subsequent affirmation of the concept in Chicago Mercantile Exchange $v$. Deaktor ${ }^{97}$ indicate, however, that this approach provides an independent basis for deferral. Exclusive jurisdiction, previously the core of the doctrine, was explicitly found to be unavailable under the CEA, ${ }^{98}$ although the Ricci inajority used traditional phrases in order to establish concurrent jurisdiction:

These are matters typically lying at the heart of an administrative agency's task and here they appear to be matters that Congress has placed within the jurisdiction of the Commodity Exchange Commission. ${ }^{99}$

[W]e simply recognize that Congress has established a specialized agency that would determine either that a membership rule of the Exchange has been violated or that it has been followed. ${ }^{100}$

These statements establish no more than an option to use the agency, for if the issue was exclusively committed to the agency there would be no need for further inquiry into the material aid to be achieved through deferral. Thus the holding must be interpreted as an innovation within the doctrine which will ease the restrictions on court use of agency procedures.

Material aid, as defined by the majority in Ricci, would result from deferral to agency processes because either of two consequences could follow: (1) if the agency finds a violation of the rule, the issues in the court case will be simplified ("the immunity issue will dissolve"); or (2) if the agency finds comphance with the rule, the court will be in a position to make a "more informed and precise determination" on the merits of immunity. ${ }^{101}$ This minimal quantum of aid will be present in almost any circumstance.

In addition, the material aid rationale implies the use of adminisstrative resources to screen or preprocess cases, without allowing the agencies power to make ultimate decisions on factual or legal issues. Such aid can contribute to a court's analytic capability by providing a distilled factual record along with the agency's advisory views on spe-

violations of the Act if it would not be in the public interest to do so. 7 U.S.C. $\$$ $13 c(b)$ (1970). Arguably, this potential conflict can best be avoided if the agency goes first.

97. 414 U.S. 113 (1973).

98. 409 U.S. at 302 n.13.

99. Id. at 305. Such jurisdiction was said to be "adjudicative and remedial." Id. at 298.

100. Id. at 307 .

101. Id. at 306. 
cific issues. It can also help to reduce court workloads by reducing the number of cases and issues which must be finally adjudicated.

\section{B. Benefit of Agency Analysis}

Material aid, according to the Ricci opinion, will occur when a court possessing an agency record will be in a better position to make a judgment on the merits than it would be if it lacked the record. ${ }^{102}$ It is easy to meet the requirements of such a test because a court will always be somewhat better off with a record which distills and organizes the case. The Ricci majority did not specify how such a record will promote a better subsequent decision on the question of immunity, nor did it justify the implicit assumption that an agency record would be superior to a district court record. Furthermore, it gave no factors which can be used to determine what is the requisite minimal quantum of aid or which can be balanced against the immediate benefit to the court. $^{103}$

The aid which the Court may have expected in Ricci was an advisory opinion from the agency on its own jurisdiction and the justification for the disputed rule. Even though the Commission had no power to decide either of these questions with finality, ${ }^{104}$ it would certainly have extensive experience and views on subjects so vital to its everyday function. Justice Marshall's dissenting opinion argued strenuously that the agency had no jurisdiction to decide whether the membership transfer rules were necessary to make the regulatory act work and that an agency finding that the rules had been obeyed was not conclusive. ${ }^{105}$ Granting that the agency's views were only advisory, the majority responded that deferral could be justified on a theory of judicial economy and was not limited to cases in which a threshold finding of exclusive jurisdiction was possible. The majority saw a benefit to be gained by providing the Commission with an opportunity to disapprove the rule itself or to build up a record relating to the self-regulatory justification for the rule and the manner in which it was applied by the defendants. This record would provide a factual background for the court's eventual decision on whether the CEA provided an antitrust defense.

The most narrow question on which the majority foresaw aid was that of whether Ricci's membership had been validly transferred under

102. Cf. Weidberg v. American Airlines, Inc., 336 F. Supp. 407, 409 (N.D. III. 1972).

103. The dissenting opiniou of Justice Marshall did pursue such a balancing approach, but not in a very convincing manner. 409 U.S. at 309-10, 317-18. See also the coinmentators mentioned in note 87 supra.

104. The majority conceded this lack of power. 409 U.S. at 307.

105. Id. at 309-10, 317-18. 
the exchange rules. Among the factual questions whose answers would affect this determination were: Did Ricci revoke the authorization before or after the transfer? Was the authorization valid? Did Siegel (the exchange member) have a lien on Ricci's membership? Did Siegel owe fees to Ricci? If so, could the fees be offset against the debt? ${ }^{108}$ Judged against the existing doctrine of primary jurisdiction, discussed in United States v. Western Pacific Railroad Co., ${ }^{107}$ these were not the type of complex technical issues that call for deferral. ${ }^{108}$ The central issue of the case, whether the rule had been applied to the plaintiff as part of a conspiracy to suppress his competition, is within the normal coinpetence of an antitrust court. In contrast, discriminatory use of a rule is not a special focus of the CEA or of disciplinary proceedings under it.

Nonetheless, the Court apparently felt that the Commission had an advantage over a district court because of special knowlege regarding "the scope, ineaning and significance of Exchange membership rules" and "the customs and practices of the imdustry and of the unique marketplace involved in this case." ${ }^{09}$ These phrases are of particular significance because the scheme of self-regulation established by the CEA differs markedly from the system in other regulated industries where the doctrine of primary jurisdiction originated. The roles of the Commission and the Secretary of Agriculture vary on different issues, ${ }^{110}$ but a major part of the regulatory burden is borne by the exchanges, which are privately controlled. The exchanges are intermediate regulatory bodies, acting as market organizers, arbiters and policemen-clearly having more independence and cohesion than voluntary groupings of firms like the conferences under the Shipping Act. It is easy to over-

106. Id. at 305 n.15.

107. 352 U.S. 59, 64-66 (1956).

108. The standards set forth in Western Pacific form one guidepost for the requisite degree of complexity. See text accompanying notes 49-51 supra. For a recent example showing how technical complexity may be involved with an exclusive jurisdiction possibility as well, see Weinberger v. Bentex Pharmaceuticals, Inc., 412 U.S. 645 (1973). In a grant of primary jurisdiction to the FDA to decide the "new drug status" under 21 U.S.C. $\$ 321(p)(1)(1970)$, the Court cited Ricci and the complexity of "chemical and medical" matters underlying the decision. See also Watts v. Missouri-Kansas-Texas R.R., 383 F.2d 571, 583 (5th Cir. 1967).

109. 409 U.S. at 305.

110. See generally Campbell, Trading in Futures Under the Commodity Exchange Act, 26 Geo. Wash. L. REv. 215 (1958); Vogelson, Tightened Regulation for Commadity Exchanges, 55 A.B.A.J. 858 (1969); Wolff, Comparative Federal Regulation of the Commodities Exchanges and the National Securities Exchanges, 38 GEo. WaSH. L. REv. 223 (1969); Note, Federal Regulation of Commodity Futures Trading, 60 YALE L.J. 822 (1951). 
state the delicate balance of such a scheme and the need for coordination of its many facets, ${ }^{111}$ but there is an obvious benefit to be derived from having cases processed first by the agency which is familiar with, and continually involved in, these institutions. Such an agency is likely to be more sensitive than the courts to extralegal and informal restraints which serve to control the market.

This analytic rationale for deferral was applied in Feliciano $v$. Romney. ${ }^{112}$ At issue was the validity of actions taken by a state redevelopment agency in providing relocation under the Model Cities Act. ${ }^{113}$ Crucial factors in favor of deferral were that the underlying facts were disputed, the programs were comprehensive in nature and developed by experts at HUD, and there was a chance that the case might be disposed of at the agency level. If the case fimally reached the court, "the facts developed by HUD, such as the quality and extent of the relocation provided for area residents, would be of substantial assistance to the court in deciding the constitutional claims."114 This was not a statutory deferral, but one based upon convemience.

Issues referred to the agency must, if the agency's review is to provide analytic aid, be directly relevant to the central issue before the court. $^{115}$ Justice Marshall argued in his dissenting opinion, for example, that in Ricci the issue of violation was not relevant to the immunity question because it was not an essential element on the merits. ${ }^{110}$ The error in that view is that compliance with an immune rule may well establish immunity; therefore, unless the rule itself is unjustified on its face, it is inproper to decide the immunity question before a determination of violation. ${ }^{117}$ In any event, the issue referred need not be an "element" of the case so long as prior decision would expedite court treatment of the other issues in the suit. ${ }^{118}$

111. Advocates of deferral may contend that the agency understands "the exigencies" of the marketplace and "the perturbations" of it during a relevant time span. Workshop I: Regulated Industries, 43 ANTITRUST L.J. 125, 144, 147 (1973) (remarks of Mr. Jerrold E. Salzman). Such a formulation reveals how thin is the line between expertise and favoritism.

112. 363 F. Supp. 656 (S.D.N.Y. 1973).

113. 42 U.S.C. $\S \S 3301-74$ (1970).

114. 363 F. Supp. at 676 .

115. Federal Maritime Bd. v. Isbrandtsen Co., 356 U.S. 481, 521 (1958) (dissenting opinion); McClenaghan v. Union Stock Yards Co., 298 F.2d 659, 668 (8th Cir. 1962); Kelly v. Union Stockyards \& Transit Co., 190 F.2d 860, 864 (7th Cir. 1951); United States v. R.J. Reynolds Tobacco Co., 325 F. Supp. 656, 663 (D.N.J. 1971), cert. denied, 410 U.S. 964 (1973).

Intervention by the agency in court may be a better solution to the expertise problem when au agency decision would be only "peripheral" to the issue in court. Maddock \& Miller, Inc. v. United States Lines, 365 F.2d 98, 102 (2d Cir. 1966).

116. 409 U.S. at 317-18. Cf. Comment, supra note 87, at 96, 103.

117. See text accompanying notes 94-96 supra.

118. Monsanto Co. v. United Gas Pipe Lime Co., 360 F. Supp. 1054 (D.D.C. 1973) 
Material aid should not be used on issues where either the exclusive jurisdictoin or Carnation's "arguably lawful" standards are more appropriate. Where a statute clearly requires that agency action be binding, it is erroneous to employ a material aid test which detracts from the effect of agency findings. ${ }^{119}$ This admonition is true even in a selfregulatory context. Likewise, if there is a high probability that agency approval will be sanctioned by the statute, the proper focus of analysis is upon "arguably lawful" aspects. Only where an issue such as immunity is ultimately for the court to decide is material aid the proper focus.

The material aid test's lack of precision was illustrated by the court of appeals decision in Deaktor, ${ }^{120}$ one of the first cases to apply the new doctrine. It was a consolidation of two cases, both of which alleged manipulation of a commodity market and one of which also contained an antitrust count. ${ }^{121}$ The common issue in the two cases was whether the district court should proceed without waiting for an adjudication by the Commodity Exchange Commission. The majority and concurring Seventh Circuit opimions both distinguished Ricci and held that the district court did not have to stay the actions. ${ }^{122}$ In the proc-

(referral of quantity issue to FPC made before court decided rate issue).

119. Two recent cases show how a particular statute may point to a test other than material aid. In Macom Products Corp. v. American Tel. \& Tel. Co., 359 F. Supp. 973, 977 (C.D. Cal. 1973), the court cited Ricci, but its analysis focused on the exclusivo jurisdiction of the FCC to determine reasonable practices (47 U.S.C. $\$ \$ 201 \mathrm{~b}, 208$ (1970)). In Otter Tail Power Co. v. United States, 410 U.S. 366 (1973), Justice Stewart, dissenting, attempted to use the three-point test of Ricci (see text accompanying note 93 supra) for deferral to an administrative agency of an antitrust action in making an argument for what was at least arguably an exclusive remedy. The majority gave relief which potentially conflicted with the FPC's power to order interconnection (16 U.S.C. $\$ 824 a(b)(1970)$ ) and the FPC's policy of not ordering "wheeling" (City of Paris, Kentucky v. Kentucky Util. Co., 41 F.P.C. 45, 49 (1969)).

120. Deaktor v. L.D. Schreiber \& Co., 479 F.2d 529 (7th Cir. 1973), rev'd sub nom. Chicago Mercantile Exch. v. Deaktor, 414 U.S. 113 (1973).

121. Deaktor itself was a class action against the Chicago Mercantilo Exchange and various of its members, alleging that the meinbers violated 7 U.S.C. $\$ 13(\mathrm{~b})$ (1970) by manipulating the July 1970 frozen pork bellies futures market upwards and squeezing out those-like the plaintiff-who had sold short. The exchange was charged with failing to exercise reasonable care with respect to detecting and halting such manipulation. 7 U.S.C. $\$ 7 \mathrm{a}(8)$ (1970). The second case, Phillips v. Chicago Mercantile Exchange (No. 71-1892), charged the exchange and certain of its nembers and officers with monopolization of the March 1970 fresh eggs futures market, in violation of the CEA, 7 U.S.C. $\$ \S 7 \mathrm{a}(8), 13(\mathrm{~b})(1970)$, and the Sherman Act, 5 U.S.C. $\$ \S 1,2$ (1970). In the later case the exchange's Business Conduct Committee had ordered a liquidation of one-half of all outstanding egg contracts, in order to counter a manipulation attempt, but the result was a price decline to the plaintiff's disadvantage.

122. The majority opinion of Judge Sprecher distimguished Ricci on three grounds. First, there was no need to resolve conflicting statutes (immunity issue) except for the one antitrust count. Second, there was no issue of the validity of an exchange rule but only an alleged violation of one. Third, the conduct was not "arguably protected," but was a direct violation of the Commodity Exchange Act. All of these distinctions rely 
ess they relied upon many perfunctory cliallenges to deferral which persist in the primary jurisdiction area. All of the judges disposed of the material aid test by expressing intuitive characterizations of the facts as uncomplicated and by discounting expertise as overrated anyway. ${ }^{123}$ The judges also utilized the argument that "manipulation" was not "arguably protected." 124

As framed by the lower court the factual issues related closely to issues of regulatory policy. The key questions were several: Had the Commission set quantitative limits for pork bellies and fresli egg futures? Had the defendant members exceeded such limits? Had they caused unreasonable price fluctuations? Should the exchange have known or did it know about the activities of its members? Should the exchange have acted to stop such activities? ${ }^{125}$ The latter three issues are inatters of judgment and reasonableness, which inust ultimately be tested by a legal standard but which must take account of market conditions.

It may be that the activities of the members' cartels in these markets were so notorious, in hindsight, that their conduct was illegal beyond any doubt. But the key question is whether the exchange's reaction to these cartels was justified. Taken together, the coinplanits in Deaktor show the exchange on the horns of a dilemma. One charged insufficient vigor in preventing an act of manipulation (which was penalized after the close of the market by fines and suspensions), while the other charged overreaction to a threat of manipulation (by forced sales of outstanding positions)-both to the detriment of plaintiffs. ${ }^{126}$

A credible statutory and practical case can be made on these facts that all prosecutions for and self-regulatory responses to manipu-

on acceptance of the complaint at face value, which makes it possible to plead around the doctrine. Analysis should focus on the degree of arguable immunity and materiality evidenced by the Ricci facts themselves, which is indeed minimal. Based upon such a comparison of facts, Deaktor presented a stronger case for deferral than Ricci using either a uniformity or an expertise ratiouale.

There are indications that the excliange intended to raise the primary jurisdiction point first on the inuch stronger fact situations of Deaktor and Phillips. Ricci reached the Supreme Court first so the exchange had no choice but to proceed. However, the exchange won nevertheless. Workshop I: Regulated Industries, 43 ANTITRUST L.J. 125, 143 (1973) (remarks of Mr. Jerrold E. Salzman).

123. 479 P.2d at 533 . See text accompanying note 62 supra. The concurring opinion of Judge Castle relates the appellants' claim that the manipulation issue turns upon "the determination of relevant market conditions, the existence of price fluctuations, and the advisability and legality of their activity," but he too concluded that the fact issues were "unobtrusive." 479 F.2d at 536, 538.

124. 479 F.2d 533, 535 .

125. Id. at 537 .

126. See note 121 supra. 
lation should originate before the agency. ${ }^{127}$ In addition, the conduct alleged might well have been "arguably lawful" in the Carnation sense. ${ }^{128}$ Certainly the conduct is "arguably lawful" in the Ricci sense, which is to say that the court might ultimately find the exchange's response to be justified and within its self-regulatory duties.

The Supreme Court's per curiam opinion in Deaktor ${ }^{120}$ did little more than reiterate Ricci and reverse the court of appeals' result. The opinion included language supporting deferral on the basis of exclusive jurisdiction ("heart of the task"130), technical construction ("intricate and technical facts of the commodity industry"131) and material aid ("sufficient aid", ${ }^{132}$ "great help"133) to produce a result with no analytic structure. Its characterization of the manipulation issue does not recognize any material distinctions from the Ricci facts. ${ }^{134}$ The Court may have been aggravated by the affront to its new principle in a case

127. Judge Castle made, in passing, a statutory argument in favor of exclusive jurisdiction of the Commission and the Secretary over manipulation cases. 479 F.2d at 536 n.2. The CEA provides three penalties for manipulation and each of them requires a prior finding of violation by the agency before the penalty is enforced in court. 7 U.S.C. $\S \S 8,9,13,13 a, 13 b$ (1970). The fourth remedy, damages, should therefore, it can be argued, follow this same pattern.

While the majority is correct that violation of the act does create an implied private right of action, it may still be the intent of the statute to require an initial hearing by the agency. The practical argument in favor of initial processing at the administrative level is that the courts may thereby concentrate on the legal issues. See Cargill, Inc. v. Hardin, 452 F.2d 1154, 1170 (8th Cir. 1971); Volkart Bros. v. Freeman, 311 F.2d 52, 58 (5th Cir. 1962). See also Case Comment, Commodities: Futures Control: Manipulation under the Commodity Exchange Act, 57 Mins. L. REv. 1243 (1973); Comment, Manipulation of Commodity Futures Prices-The Great Western Case, 21 U. CHr. L. Rev. 94 (1953).

128. The "arguably lawful" nature of the exchange's action, in the Carnation sense, may be found in the Secretary's power to disapprove rules if the rules were in faet complied with, or in the power to disregard minor violations. See 7 U.S.C. $\$ \S 12 \mathrm{a}(7), 13 \mathrm{c}$ (b) (1970). A risk of interference argument was inade by the lower court in Ricci: if the agency is bypassed, persons will be discouraged from complaming to the Commission or the Secretary, who will then be less able to carry out their regulatory tasks. 447 F.2d at 719 (7th Cir. 1971).

129. 414 U.S. 113 (1973). Justice Stewart was the lone dissenter, referring to Judge Castle's concurring opinion.

130. Id. at 114 .

131. Id. at 115 .

132. Id.

133. Id. (quoting Ricci, 409 U.S. at 307).

134. In our judgment, the Court of Appeals, as in Ricci, should have requested the District Court to stay the proceedings in the Phillips case to afford an opportunity to invoke the jurisdiction of the Commission. For very similar reasons, the Deaktor plaintiffs, who also alleged violations of the CEA and the rules of the Exchange, should be routed in the first instance to the agency whose administrative functions appear to encompass adjudication of the kind of substantive claims made against the Exchange in this case.

414 U.S. at 115. This holding also makes clear that the presénce of an antitrust count is not a major variable in performing the analysis. 
so similar to Ricci, but the reversal emphasizes that the Court is serious about the transfer of case preparation to agencies.

The lower court opinion in Deaktor has been the most glaring case to date of an attempt to avoid the holding of Ricci by minimizing the complexity of the issues and the resultant worth of analytic aid. Other cases have also displayed this tendency, ${ }^{135}$ indicating how difficult it may be to control the exercise of discretion with a test-naterial aidwhich is as vulnerable to subjective manipulation as was the traditional "expertise" rationale.

\section{Allocating Court Resources}

Because the Ricci case posited deferral on a rather limited quantum of analytic aid, one suspects that the true inotivation for the holding lies elsewhere. This motivation may well be found in the current concern of the Chief Justice and others over judicial administration and the workload of federal courts. ${ }^{136}$ If so, an important factor to be evaluated in primary jurisdiction decisions is the effect of deferral upon optimal use of the judicial system's resources. ${ }^{137}$

One effect was expressly mentioned by the Court in Ricci. If a violation of exchange rules were found by the Commission, there would be no need for the courts ever to deal with the antitrust immunity issue-it "will dissolve." ${ }^{138}$ This interest could be generalized to weigh any issues that may be eliminated by agency action. Court resources could also be saved by a deferral decision if, as a consequence, the plaintiff gives up the suit, the parties settle out of court, the defendant wins before the agency and the plaintiff then elects not to continue, or the planitiff is satisfied with the administrative remedy. A inajor

135. Seligson v. New York Produce Exch., 363 F. Supp. 338 (S.D.N.Y. 1973); United States v. Morgan Drive Away, Inc., 1974-1 Trade Cas. I 74,888 (D.D.C. 1974); United States v. National Broadcasting Co., Inc., 1974-1 Trade Cas. \ 74,885 (C.D. Cal. 1974).

136. See Burger, The State of the Judiciary-1970, 56 A.B.A.J. 929 (1970); Carrington, Crowded Dockets and the Courts of Appeals: The Threat to the Function of Review and the National Law, 82 Harv. L. Rev. 542 (1969); Sykes \& Isbell, Court Congestion and Crash Programs: A Case Study, 44 Denver L.J. 377 (1967); Green, A Pro-Business Tilt in the Courts?, Wall St. J., June 10, 1975, at 22, col. 3 (Pac. ed.).

137. The "efficient administration of justice" was used as a factor against primary jurisdiction, in combination with a weak case of arguably lawful conduct centering on the scope of an agreement previously approved by the $\mathrm{CAB}$, in Breen Air Freight, Ltd. v. Air Cargo, Inc., 470 F.2d 767, 774 (2d Cir. 1972). Accord, Allied Air Freight, Inc. v. Pan American World Airways, Inc., 393 F.2d 441, 445 (2d Cir. 1968). On the other hand, judicial economy and avoidance of duplication of effort supported deferral in Chronicle Publishing Co. v. National Broadcasting Co., 294 F.2d 744, 749 (9th Cir. 1961).

138. 409 U.S. at 306. 
thrust of the material aid approach, therefore, is to physically transfer cases to ageney hearing processes, easing the court workload. ${ }^{130}$ This objective is not adequately reflected by interpretations which einphasize that the purpose of the doctrine is to "get the agency's view."140 A primary factor to be considered in this aspect of material aid is the likelihood of final disposition at the agency level. ${ }^{141}$

It is inappropriate, however, for courts to use too parochial an approach, since the real interest is governmental efficiency as a whole. The courts should consider, therefore, not only the assumption that agency determination is less costly than court determination, but also the possible duphication of effort by courts and agencies. The policy behind deferral, in the absence of any statutory directive, may be inapposite if a court has already devoted time and energy to a case. In Seligson v. New York Produce Exchange, ${ }^{142}$ plaintiffs alleged a conspiracy to monopolize and inanipulate the cotton seed oil futures market. The court held against a primary jurisdiction motion, raised after Ricci caine down, because the case had already been in the process of discovery and pretrial motions for over seven years. This is a correct holding even after $R i c c i,{ }^{143}$ although $R i c c i$ did not discuss this aspect.

Duplication of effort may also result if a deferred case is appealed. The majority in Ricci said that agency determination would be subject to judicial review and "would obviate any necessity for the antitrust court to relitigate the issues actually disposed of . . ."144 This ghib assumption conceals two procedural problems peculiar to this statute. First, the agency findings and order may be reviewed in a court of appeals and then the Supreme Court before returning to the district court for trial. ${ }^{145}$ Second, the standard of review is "weight of the evidence,"

139. The workload problem had been previously mentioned in National Welfare Rights Org. v. Finch, 429 F.2d 725, 738 (D.C. Cir. 1970), where primary jurisdiction was made possible by the plaintiff's right to intervene before HEW. Accord, Corum v. Beth Israel Medical Center, 373 F. Supp. 558, 563 (S.D.N.Y. 1974).

140. It is often argued that the agency can intervene in the court case or file amicus briefs, thereby satisfying the policies behind primary jurisdiction. See, e.g., J $\mathrm{J}_{\mathrm{AFF}}$, supra note 1, at 133, combining the bald expertise theory of Far East with the loose dicta of Isbrandtsen.

141. Cf. Chicago Auto. Trade Ass'n v. Madden, 328 F.2d 766, 769 (7th Cir.), cert. denied, 377 U.S. 979 (1964) (exhaustion).

142. 363 F. Supp. 338 (S.D.N.Y. 1973). The case proceeded to trial on the merits. See 378 F. Supp. 1076 (S.D.N.Y. 1974).

143. The ruling on the motion did give some weight to the fallacious argument in the lower Deaktor opinion (see note 124 supra) that manipulation is not arguably lawful. This argument was effectively negated by the Supreme Court's Deaktor opinion.

144. 409 U.S. at 306.

145. 7 U.S.C. $\$ 9$ (1970); 28 U.S.C. $\$ 1254$ (1970). 
indicating that even factual findings are open to relitigation on appeal. ${ }^{140}$

Ricci was a radical directive for lower courts to utilize factual preparation by agencies whenever possible. ${ }^{147}$ It is a drastic step, not a smooth transition, justified perliaps by the current strain on the court system. The trend toward restricting agency jurisdiction has been reversed, while emphasis is directed to an older ideal of coordination and mutual benefit between courts and agencies. ${ }^{148}$ For the immediate future, the curtness of the Court's Deaktor opinion emphasizes the command that lower courts are not to denigrate the doctrine by distinguishing similar cases.

\section{Other Discretionary Factors}

The nearly automatic deferral which seems to result from the low quantum of aid required by the Ricci holding is unacceptable in the long run because of certain values in our judicial system. When the workload crisis passes, the courts will fashion new refinements of the material aid test on the basis of these values. One refinement may enable courts to retain cases involving extreme violations or public issues having a broad inpact; this might be seen as part of the process of allocating trivial cases away from the courts. Another refinement may be to concentrate on the immediate parties and the potential influence on the outcome which may ensue from deferral. Many of the relevant values have been mentioned in the historical debate over the doctrine. ${ }^{140}$ They were not compelling so long as deferral was based

146. Compare Great W. Food Distrib., Inc. v. Brannan, 201 F.2d 476, 479 (7th Cir. 1953), cert. denied, 345 U.S. 997 (1953), with General Foods Corp. v. Brannan, 170 F.2d 220, 224 (7th Cir. 1948).

147. Some commentators have cited the Ricci case for the proposition that antitrust cases are not to be referred to agencies without express statutory authority.

The Ricci case thus reaffirms the principle that antitrust issues are not to be referred to a regulatory agency (in the absence of an express statutory grant of antitrust jurisdiction to that agency) but are to be decided by the courts alone.

Senate Subcomm. on Securities of the Comm. on Banking, Housing and URBan AFFAIRS, Securities Industry Study, S. Doc. 93-13, 93d Cong., 1st Sess. 233 (1973) [hereinafter cited as SENATE STUDY]. While this statement does not distort the holding, it ignores the truism that nonreference of antitrust issues matters little if the entire antitrust case is referred under the Ricci doctrine.

148. The classic statement of the ideal of court/agency coordination was made by Justice Stone in United States v. Morgan, 307 U.S. 183, 191 (1939):

[C]ourt and agency are not to be regarded as wholly independent and unrelated instrumentalities of justice . . . . [They] are the means adopted to attain the prescribed end [of the statute], and so far as their duties are defined by the prescribed end (of the statute), and so far as their duties are defined by the words of the statute, those words should be construed so as to attain that end through coördinated action.

149. See, e.g., Kestenbaum, Primary Jurisdiction to Decide Antitrust Jurisdiction: A Practical Approach to the Allocation of Functions, 55 GEO. L.J. 812 (1967); 
upon a statutory directive, but they rise to new significance as balancing factors when deferral is solely within the discretion of the court. ${ }^{150}$

Expense and delay to the plaintiff is a factor which is invariably stressed in arguments opposing deferral. This factor should not, however, be unduly emphasized just because it is always present, nor should it be used to routinely deny primary jurisdiction. ${ }^{161}$ Justice Marshall in Ricci weighed such expense directly against the aid to be derived, ${ }^{152}$ but such a weighing process is so open to subjective biases of judges that it should be restrained. A plaintiff should have to prove particularly and with high certainty that the burden caused by deferral will affect him more than in the normal case-and such proof should coincide with a low level of materiality. On the other hand, delay need not cause injury as severe as the "irreparable injury" required under the doctrine of exhaustion. ${ }^{153}$ One solution is to set a limit on the delay which will be allowed. ${ }^{154}$

Schwartz, Primary Administrative Jurisdiction and the Exhaustion of Litigants, 41 GEo. L.J. 495 (1953); Schwartz, Legal Restrictions of Competition in the Regulated Industries: An Abdication of Judicial Responsibility, 67 HARv. L. Rev. 436 (1954); Latta, Primary Jurisdiction in the Regulated Industries and the Antitrust Laws, 30 U. CIN. L. REV. 261 (1961).

150. The concept of weighing factors in a primary jurisdiction decision received soine support in Note, Antitrust and the Regulated Industries: The Panagra Decision and Its Ramifications, 38 N.Y.U.L. Rev. 593, 611-13 (1963).

151. Western Union Telegraph Co. v. Graphic Scanning Corp., 360 F. Supp. 593 (S.D.N.Y. 1973), finding primary (actually exclusive) jurisdiction of the FCC under a uniformity and expertise approach, inade a cogent point about delay-it cannot be a persuasive factor because the courts themselves are no faster these days. Id. at 596 n.2. The active supervision of the FCC in the dispute was also decisive. 28 F.C.C.2d 207, 276 (1971).

In Chronicle Publishing Co. v. National Broadcasting Co., 294 F.2d 744, 749 (9th Cir. 1961) the delay involved was said to arise only because of the complexity of the litigation and thus was not immoderate in the circumstances.

152. 409 U.S. at 321. Cf. Japan Lines, Ltd. v. Sabre Shipping Corp., 407 F.2d 173, 175 (2d Cir.), cert. denied, 395 U.S. 922 (1969); Catholic Medical Center v. Rockefeller, 305 F. Supp. 1256, 1267 (E.D.N.Y. 1969), aff'd, 430 F.2d 1297 (2d Cir.), appeal dismissed, 400 U.S. 931 (1970); Marnell v. United Parcel Serv. of America, 260 F. Supp. 391,414 (N.D. Cal. 1966) (where the delay was said to defeat the policy of the antitrust laws).

153. This is so because by definition there is no exclusive jurisdiction, such as there is in exhaustion cases, to be weighed against the costs of delay. The mere burden of submitting to agency hearings is not such "irreparable harm" as will justify court intervention in agency proceedings. Sears, Roebuck \& Co. v. NLRB, 473 F.2d 91, 93 (D.C. Cir. 1972), cert. denied, 415 U.S. 950 (1974) (exhaustion).

Irreparable injury may be more likely in the litigation of environmental issues. See generally Note, Primary Jurisdiction in Environmental Cases: Suggested Guidelines for Limiting Deferral, 48 IND. L.J. 676 (1973) and cases cited therein at 683-87.

154. A six-1nonth limitation on the delay which would be permitted was employed in Monsanto Co. v. United Gas Pipe Line Co., 360 F. Supp. 1054 (D.D.C. 1973). The case was referred to the Federal Power Commission for determination of a quantity issue, after which the court would decide a damages issue in a more concrete context. Such a solution was explicitly based upon "judicial economy." Id. at 1057. See also 
A variant of the expense and delay factor is the deterrent effect upon other plaintiffs who might contemplate bringing similar suits, especially if the subject of the litigation is of public interest. This argument must be handled cautiously, because there may be a very low likelihood of success on the merits or the agency may be more favorable to plaintiffs than some courts. In the absence of proof of bias, the mere assertion of such an effect should not carry the decision.

Prospective due process defects may also be considered, if clearly substantiated. Justice Marshall's dissent catalogued a host of hypothetical problems: the plaintiff could not force a hearing, he liad no right of intervention, and there would be unreasonable delay. ${ }^{155}$ Such nebulous possibilities should not be given great weight until they happen, and certainly they do not destroy jurisdiction. The plaintiff may, of course, be able to prove some specific, unusual defect, but should not be able to complain in vague generalities about administrative agencies. ${ }^{150}$

A fourth factor is potential agency bias in favor of the industry of a magnitude giving rise to a predictable outcome unfavorable to a plaintiff. Justice Douglas argued that since the agency in Ricci had not acted on the alleged problem, any finding of violation would be an admission of failure to properly regulate-so that deferral was futile. ${ }^{157}$ Such logic is as unwarranted as is an assertion that there is no problem of bias at all. Evidence that the agency has among its several statutory goals the economic lealth of the regulated firms and the continuing viability of the particular industry should not suffice to prove bias of the requisite magnitude. However, it may be possible to prove futility, perhaps by a past record of bad faith dealings with this particular plaintiff. ${ }^{158}$

Macom Products Corp. v. American Tel. \& Tel. Co., 359 F. Supp. 973, 978 (C.D. Cal. 1973) (seven month limit). The propriety of courts attempting to so dictate the course of the agency proceedings has been questioned. Miron, Primary Jurisdiction, 43 ANTITruST L.J. 329, 340-42 (1974). In Chastain v. American Tel. \& Tel. Co., 351 F. Supp. 1320,1323 (D.D.C. 1972), the court expressly put no limit on the scope of the agency investigation.

155. 409 U.S. at 310-12. See generally Comment, Due Process Rights of Participation in Administrative Rulemaking, 63 CALIF. L. Rev. 886 (1975).

156. The inability of the plaintiffs to participate in HEW's procedure for review of the challenged welfare programs was a factor against deferral in Rosado v. Wyman, 397 U.S. 397 (1970).

157. 409 U.S. at 308-09. This argument was reiterated in Fredrickson \& Co. v. Merrill Lynch, Pierce, Fenner \& Smith, Inc., CCH FED. SEC. L. REP. T 94,792 at 96,631 (N.D. III. 1974).

158. Courts should not assume in advance that an administrative hearing will not be fairly conducted. Fahey v. Mallonee, 332 U.S. 245, 256 (1947). The plaintiff should have to present an undispnted allegation of fundainental prejudice. Cf. United States v. Litton Indus., Inc., 462 F.2d 14, 17 (9th Cir. 1972) (exhaustion); Amos Treat \& Co. v. SEC, 306 F.2d 260 (D.C. Cir. 1962) (combination of investigation and adjudication in one individual). 
A final problem, perhaps the most perplexing one in the whole doctrine of primary jurisdiction, is how to avoid a binding influence on the result by the agency's findings of underlying facts. For instance, in Ricci the court said that it would accept the findings on "issues actually disposed of"150 and then somehow go on to determine the immunity issue as a inatter of law. Yet certain factual determinations, such as those about reasonableness of conduct or the defendant's motives, could lead inevitably to a conclusion on antitrust liability. In cases involving the right to a jury trial ${ }^{160}$ or the deprivation of constitutional rights, ${ }^{1{ }^{161}}$ there seems to be authority for giving the findings only prima facie effect. There clearly is a trade off between inaterial aid and substantive power over the issues. The Ricci court seemed to be willing to give up such power in the interest of simplifying issues and reducing the court systein's workload. Later courts inay be more heavily influenced by the other values at stake or the economic impact of a case (neither of which were very great on the Ricci facts). They may wish to avoid even the slightest "taint" of the ultimate resolution of the case. ${ }^{162}$ The technique of "certifying" issues to the agency, i.e., referral with a specification that the resulting views will be merely advisory, ${ }^{163}$ is a solution to the problem, but not one in which agencies are likely to cooperate. ${ }^{164}$

159. 409 U.S. at 306 . In fact, the findings under that statute did not have even a minimal binding nature. See text accompanying note 146 supra.

160. Cox v. United States, 332 U.S. 442 (1947) (the record of the administrative proceeding was presented to the jury as part of the evidence). But see Yakus v. United States, 321 U.S. 414, 444-45 (1944) (no jury trial required in criminal case); NLRB v. Jones \& Laughlin Steel Corp., 301 U.S. 1, $48-49$ (1937) (seventh amendment not applicable to a procedure set up before an administrative body).

See generally Fraenkel, Can the Administrative Process Evade the Sixth Amendment?, 1 SYR. L. Rev. 173 (1949); von Mehren, The Antitrust Laws and Regulated Industries: The Doctrine of Primary Jurisdiction, 67 HARv. L. Rev. 929, 963 (1954); White, Processing Conscientious Objector Claims: A Constitutional Inquiry, 56 CalIP. L. REv. 652, 668-70 (1968).

161. Ohio Valley Water Co. v. Ben Avon Borough, 253 U.S. 287 (1920); cf. Conant, In Defense of Administrative Regulation, 39 IIv. L.J. 29, 65-66 (1963) (prima facie effect may not satisfy due process objections). See generally 4 Davis, supra note $1, \$ 29.09$.

162. For instance, certain cases alleging racial discrimination were withheld from agencies. Fitzgerald v. Pan Am. World Airways, Inc., 229 F.2d 499 (2d Cir. 1956) (CAB); Solomon v. Pennsylvania R.R., 96 F. Supp. 709 (S.D.N.Y. 1951) (ICC).

163. There is authority for the court to specify a minimum list of issues which the agency will decide. Arizona Sand \& Rock Co. v. Southern Pac. Co., 280 I.C.C. 285 (1951). Yet the procedure of certifying issues used in International Heat \& Frost Insulators Ass'n v. United Contractors Ass'n, 483 F.2d 384 (3d Cir. 1973), modified, 494 F.2d 1353 (3d Cir. 1974), would seem to be abnormal.

For authority treating referral to the agency as akin to use of a master, see Susquehanna \& Western R.R. v. Follmer, 254 F.2d 510 (3d Cir. 1958). As such the results would be binding upon a judge "unless clearly erroneous" and would be "mere evidence" to a jury. FeD. R. Crv. P. 53(e) 2 \& 3. See also cases cited in note 85 supra.

164. In Atlantic Freight Lines, Inc., 51 M.C.C. 175, 186 (1949) the ICC insisted 


\section{V \\ PRIMARy JURISDiction APPIIED: DeferRal Under the SECURITIES EXChange ACt}

\section{A. Analytic Framework}

As has already been discussed, primary jurisdiction doctrine has developed out of cases treating a variety of regulatory contexts. Early cases centered on the ICC, an agency with statutory authority to exercise pervasive economic control over its industries. The subdoctrine of exclusive agency jurisdiction served workably to allocate decision1naking on the interpretation and application of sucl regulatory powers. Its invocation is an appropriate judicial response where power to resolve a contested issue is clearly granted by statute to a regulatory agency.

The doctrine was expanded in order to reconcile conflicting policies of regulatory and antitrust laws. The Shipping Act, which authorized antitrust immunity under certain conditions, served as a focus for developments on this question, particularly the establishment of an "arguably lawful" test for primary jurisdiction deferral. In the Shipping Act cases the scope, not the existence, of agency power to provide antitrust immunity was at issue. Where an agency's power to provide immunity under a specific set of facts is contested, actual exercise of agency power to explore facts and rule on the application of regulatory law properly serves as the foundation for judicial determination of scope and binding effect under the statute.

Ricci and Deaktor applied primary jurisdiction to a regulatory scheme that provides no express immunity power. Conduct is "arguably lawful" not because it may potentially be sanctioned by the regulatory agency but because it may be justified by the court which compares and construes competing statutory policies. Deferral appears to depend on the material aid to be derived by a court from prior agency review, creation of a record and expression of expert views. Such a

upon its right to construe its own orders. In other cases, the suit was only in the courts because the agency declined to assert jurisdiction. See, e.g., Pacific Seafarers, Inc. v. Pacific Far East Line, Inc., 404 F.2d 804, 811 n.19 (D.C. Cir. 1968); United States v. Pacific Southwest Airlines, 358 F. Supp. 1224, 1230 (C.D. Cal. 1973); Seatrain Lines,

Inc. v. Pennsylvania R.R., 108 F. Supp. 113, 123, 126 (D.N.J. 1952).

A court's dilemina is illustrated by Israel v. Baxter Laboratories, Inc., 466 F.2d 272, 280 (D.C. Cir. 1972), where the judge indicated that review of questions relating to antitrust would not be limited by the statute (21 U.S.C. $\$ 355(\mathrm{~b})(1970)$ ) or by the APA (5 U.S.C. $\$ 706(1)(1970)$ ). At the saine time, he hoped that the FDA would make "its customary thorough investigation," even though its findings could be set aside. 466 F.2d at 283. 
concept seems particularly applicable to regulatory schemes that sanction and rely in large part on private controls, as in the private exchange system of the commodity futures industry.

Expansion of the material aid concept to other regulatory schemes and agencies seems certain. A likely area for its utilization is the regulation of securities. The structure of market regulation and the statutory frainework of the Securities Exchange Act of 1934 (SEA) ${ }^{105}$ are in many ways similar to the commodities context which produced Ricci and Deaktor. Moreover, the division of roles between the courts and the Securities Exchange Commission (SEC) has been the subject of continuing htigation. Finally, substantive and procedural reforms are pending which will increase the areas of concurrent jurisdiction in which the doctrine is applicable. The remaining part of this Comment examines primary jurisdiction doctrine as it has developed in the securities industry setting and as it might be applied using the material aid rationale. Although antitrust immunity has until now been the focal point of concern, the possibilities for judicial deferral under the doctrine apply in other SEA contexts as well. Each of the three major primary jurisdiction theories applies to particular groups of problems within this statute. More generally, application of primary jurisdiction analysis to the SEA suggests how such analysis can proceed where other regulatory schemes are at issue.

\section{B. Concurrent Jurisdiction of the SEC}

Although section 27 of the SEA gives district courts "exclusive jurisdiction" over violations of the SEA or rules and regulations thereunder, this language was intended only to exclude actions in state courts. $^{168}$ Administrative adjudication pursuant to section 19(a) is

165. 15 U.S.C. $\$ \S 78$ a to $78 \mathrm{hh}-1$ (1970) [hereinafter cited as SEA]. The Act was originally enacted as Act of June 6, 1934, ch. 404, 48 Stat. 881; principal amendments have been the Maloney Act, Act of June 25, 1938, cl. 677, 52 Stat. 1070; Act of Aug. 20, 1964, Pub. L. No. 88-467, 78 Stat. 565; the Willians Act, Act of July 29, 1968, Pub. L. No. 90-439, 82 Stat. 454; Securities Acts Amendments of 1975, Pub. L. No. 94-29, 89 Stat. - (June 4, 1975) [hereinafter cited as Reform Act].

See generally Cary, Self-Regulation in the Securities Industry, 49 A.B.A.J. 244 (1963); Jennings, Self-Regulation in the Securities Industry: The Role of the Securities and Exchange Commission, 29 LAW \& CONTEMP. ProB. 663 (1964); Wolff, stura note 110; Senate Study, supra note 147; House Subcomm. on Commerce and Finance of the Comm. on Interstate and Foreign Commerce, Securities Industry Study, H.R. REP. No. 92-1519, 92d Cong., 2d Sess. 137-204 (1972).

166. 15 U.S.C. \& 78aa (1970). See, e.g., Morganbesser v. NYSE, CCH FeD. SEC. L. REP. If 93,210 (N.Y. Sup. Ct. 1971); Schnall v. Loeb, Rhoades \& Co., CCH FED. SEC. L. REP. T 93,104 (N.Y. Sup. Ct. 1971); Reuben Rose \& Co. v. Davon, CCH FED. SEC. L. Rep. II 92,109 (N.Y. Sup. Ct. 1967). See also American Distilling Co. v. Brown, 295 N.Y. 36, 64 N.E.2d 347 (1945); Investment Associates, Inc. v. Standard 
clearly not restricted by section $27,{ }^{107}$ nor are the various SEC rulemaking powers. The pattern of these powers differs with respect to transactions on organized exchanges and in over-the-counter (OTC) markets. Rulemaking for exchange inarkets is authorized by section 19(b) of the SEA, which gives the SEC power to "alter or supplement" exchange rules concerning a specified list of inatters, ${ }^{168}$ and several other sections which provide for making regulations to control various trading and financing practices. ${ }^{169}$ Adjudication of violations is authorized by section 19(a), which allows the SEC to suspend or deregister an exchange, a security, a member or an officer of an exchange. ${ }^{170}$ In addition, the SEC has power to "abrogate any rule" of the only existing national securities association, the National Association of Securities Dealers (NASD), ${ }^{171}$ and to "alter or supplement" rules with respect to certain listed items. ${ }^{172}$

Substantive regulations regarding the OTC market may be promulgated under several subsections. ${ }^{173}$ Adjudication regarding OTC markets is provided by review of NASD disciplinary proceedings ${ }^{174}$ and by SEC powers to censure, suspend or revoke the registration of brokers and dealers, ${ }^{175}$ associated persons, ${ }^{176}$ and OTC securities. ${ }^{177}$

Consideration of agency jurisdiction under the SEA must begin with Silver v. New York Stock Exchange. ${ }^{178}$ Plaintiff, not a nnember of the New York Stock Exchange (NYSE), claimed that his firms' private wire counections with several exchange members had been disconnected as a result of an exchange order, which allegedly constituted a conspiracy and concerted refusal to deal in violation of sections 1 and 2 of the Sherman Act. ${ }^{179}$ The rules of the exchange provided for regulation of member-nonmember dealings and specifically required approval of wire connections between members and nonmembers. ${ }^{180}$

Power \& Light Corp., 29 Del. Ch. 225, 48 A.2d 501 (Ch. 1946), aff'd, 29 Del. Ch. 593, 51 A.2d 572 (Sup. Ct. 1947).

167. 15 U.S.C. $\S 78 \mathrm{~s}(\mathrm{a})$ (1970). See Wright v. SEC, 112 F.2d 89, 95 (2d Cir. 1940).

168. 15 U.S.C. $\$ 78 \mathrm{~s}(\mathrm{~b})(1970)$. See note 196 infra.

169. 15 U.S.C. $\$ \S 78 \mathrm{~h}(\mathrm{c}), 78 \mathrm{i}(\mathrm{a})(6), 78 \mathrm{i}(\mathrm{b}), 78 \mathrm{i}(\mathrm{c}), 78 \mathrm{j}, 78 \mathrm{k}, 78 \mathrm{n}, 78 \mathrm{p}(\mathrm{e}), 78 \mathrm{dd}$

(1970).

170. Id. $\$ 78 \mathrm{~s}(\mathrm{a})(1970)$.

171. Id. $\$ 78 o-3(\mathrm{k})(1)(1970)$.

172. Id. $\$ 78 o-3(\mathrm{k})(2)(1970)$.

173. Id. $\S \S 78 \mathrm{j}(\mathrm{b}), 78 o(\mathrm{a})(2), 78 o(\mathrm{~b})(8), 78 o(\mathrm{~b})(10), 78 o(\mathrm{c})(1970)$.

174. Id. $\$ \S 78 o-3(\mathrm{~g}), 780-3(\mathrm{~b})(1970)$.

175. Id. $\$ 78 o(\mathrm{~b})(5)(1970)$.

176. Id. $\$ 780(\mathrm{~b})(7)(1970)$.

177. Id. $\$ 780$ (c)(5) (1970).

178. 373 U.S. 341 (1963).

179. 15 U.S.C. $\$ \$ 1,2$ (1970).

180. The exchange's action was apparently in accordance with NYSE Const. art. III, $\S 6$ and what are now its Rules 356, 357 and 359. 2 CCH NYSE GuIDE IIT 1106, 
The NYSE action was taken pursuant to an excliange policy of denying notice or an opportunity to be heard to nonmembers.

Deferral to SEC investigation or resolution was rejected by the Supreme Court because there was no concurrent agency jurisdiction, i.e., no available procedure by which the plaintiff could obtain SEC review of the disciplinary action taken against him by the exchange. Althougl the SEC could have disapproved any rules adopted by the NYSE, ${ }^{181}$ it could not "review particular instances of enforceinent of exchange rules."182 The Court concluded that since the SEC did not have jurisdiction to review this dispute, there was no problem of conflict between the Sherman Act and the 1934 Act and thus no need for uniformity. It then held that the exchange's actions constituted antitrust violations because they were taken without affording procedural protections of notice and hearing to the nonmember.

The Silver majority's distinction between the adoption of exchange rules and "particular applications" of them has been criticized as too facile. ${ }^{183}$ Arguably, there was a procedure whereby the SEC could decide whether or not the rule involved was "necessary or appropriate for the protection of investors." 184 While the plaintiff could not have obtained direct administrative review of the NYSE action, the SEC could have begun a proceeding to determine whether or not the exchange was enforcing its own rules. ${ }^{185}$ Such a hearing would have led

2356, 2357, 2359 (1975).

Under NYSE Const. art. XIV, $\S 14$, a hearing was provided for members in similar circumstances. 2 CCH NYSE GUIDE I 1664 (1975). A hearing was required for NASD disciplinary actions. 15 U.S.C. \& 780-3(1) (1970).

181. 15 U.S.C. $\$ 78 \mathrm{~s}($ b) (1970). After this case the SEC adopted a regulation which required proposed rule changes to be filed by the exchanges. SEA Rule 17a-8, 17 C.F.R. \$ 240.17a-8 (1974).

182. 373 U.S. at 357 . It is clear from the statute that NYSE enforcement actions are not directly reviewable. By contrast, the SEC does have such power to review disciplinary proceedings of the NASD. 15 U.S.C. $\$ \S 780-3(\mathrm{~g}), 780-3(\mathrm{~h})$ (1970). Similarly, the CEC in Ricci had power to review such actions by commodity exchanges. See note 91 supra.

183. P. AReEdA, ANTTtrust ANalysis 113 (2d ed. 1974); Baxter, NYSE Fixed Commission Rates: A Private Cartel Goes Public, 22 STAN. L. Rev. 675, 687 (1970).

184. 15 U.S.C. $\& 78 s(b)(1970)$. See text accompanying note 196 infra. The subsection under which the NYSE rules here might most arguably fit is (5), covering "the manner, method, and place of soliciting business." The Court did not consider carefully any of the provisions of section 19 (b).

Under section 6(d) of the SEA, an exchange may not be registered unless the SEC finds that its rules are "just and adequate to insure fair dealing . . . " 15 U.S.C. § 78f(d) (1970). Thus, to the extent these NYSE rules and the constitutional provision were in its original registration statement, the SEC's granting of registration should be taken as an explicit approval. However, the failure to exercise the $19(\mathrm{~b})$ powers cannot be taken as tacit approval because no fornal action was taken. Rosin v. NYSE, CCH FED. SEC. L. REP. II 93,518, at 92501 (N.D. Ill. 1972), aff'd, 484 F.2d 179 (7th Cir. 1973), cert. denied, 415 U.S. 977 (1974).

185. 15 U.S.C. $\$ 78 \mathrm{~s}(\mathrm{a})(1)(1970)$. This section provides for suspension or de- 
to a determination of whether or not the rule was in fact violated, as well as an advisory enunciation by the SEC of its views on whether the injury to competition was outside the scope of the SEA, very much in the Ricci pattern.

Overly rigid analysis of the concurrent jurisdiction requirement enabled the Court in Silver to reject deferral and reach an adverse decision on the merits of claimed antitrust immunity. Cases which have used an "arguable jurisdiction" test and other innovative devices to obtain the agency's views are probably sounder in their analysis. ${ }^{186}$

Silver's analysis of concurrent jurisdiction may now be moot, however, because recent amendments to the SEA provide for SEC review of exchange rule enforcement actions ${ }^{187}$ and expressly allow the agency to discipline an exchange which fails to enforce its own rules. ${ }^{188}$ These amendments will harmonize the SEC's powers over the exchanges and the NASD. ${ }^{180}$ With these powers, the SEC will have sufficient jurisdiction to hear almost any dispute in the industry. Although it will still not be able to enforce self-regulatory rules directly, the SEC can, under the reform bill, pass upon violations of those rules either on direct review or by actions against the exchanges for failure to enforce the rules.

\section{Exclusive Jurisdiction Over the Issue}

\section{Immunity of Structural Exchange Rules}

Various fundamental restraints on competition in securities nnar-

registration of an exchange if the SEC finds that it "has violated any provision of this title or of the rules and regulations thereunder or has failed to enforce, so far as is within its power, compliance therewith by a member ...."Id. This procedure has been used only one time in the history of the Act, in a case where one of the charges was a failure to force compliance with the exchange's own rules. See San Francisco Mining Exch., 42 S.E.C. 1004 (1966), aff'd, 378 F.2d 162 (9th Cir. 1967).

Several commentators have remarked that section 19(a)(1) is available to hear the question of whether or not the exchange itself is violating its own rules, although it is somewhat impractical because the remedy is so severe. See, e.g., 2 L. Loss, SEcurTIES REgULATION 1178 (2d ed. 1961); Westwood \& Howard, Self-Government in the Securities Business, 17 Law. \& Contemp. Prob. 518, 525 (1952); Note, Informal Bargaining Process: An Analysis of the SEC's Regulation of the New York Stock Exchange, 80 YALE L.J. 811, 814 (1971). Cf. Baird v. Franklin, 141 F.2d 238, 244-45 (2d Cir.) (dictum), cert. denied, 323 U.S. 737 (1944); Bright v. Philadelphia-Baltimore-Washington Stock Exch., Inc., 327 F. Supp, 495, 502-03 (E.D. Pa. 1971).

186. See cases cited at notes 27-29 supra.

187. Reform Act, supra note $165, \S 16$ (adding to the SEA a new section 19(d)). Disciplinary actions covered are those against any member or any person associated with a nember (which would include Mr. Silver). Exchange demals of menbership applications are also reviewable. The SEC's order is subject to judicial review under revised section 25(a) of the Act. See generally Painter, An Analysis of Recent Proposals for Reform of Federal Securities Legislation, 71 Mrch. L. Rev. 1575 (1973).

188. Reform Act, supra note $165, \S 16$.

189. Id. § 12 . 
kets have been attacked over the years, principally including: (1) the fixed minimum commission rate structure, ${ }^{100}$ (2) the anti-rebate rule, ${ }^{191}$ (3) limitations on off-floor trading by exchange members, ${ }^{102}$ (4) limited access by nonmembers, ${ }^{103}$ (5) prohibition of meinbership by institutional investors, ${ }^{104}$ and (6) price fixing in the OTC market. ${ }^{105}$ For primary jurisdiction purposes they all pose the same analytic problein: defining the extent of SEC jurisdiction over structural restraints permitted by the SEA.

Section 19(b) of the SEA provided the statutory background for most of these structural issues. ${ }^{196}$ This section, as emphasized in Silver,

190. Gordon v. NYSE, 498 F.2d 1303 (2d Cir. 1974), cert. granted, 43 U.S.L.W. 3290 (U.S. Nov. 18, 1974) (No. 74-304); Kaplan v. Lehman Bros., 250 F. Supp. 562 (N.D. Ill. 1966), aff'd, 371 F.2d 409 (7th Cir. 1967), cert. denied, 389 U.S. 954 (1967); Fredrickson v. Merrill Lynch, Pierce, Fenner \& Smith, Inc., CCH Fed. Sec. L. ReP. II 94,792 (N.D. Ill. 1974). See generally R. Jennings \& H. MARSH, SEcurities REgulatron: Cases aNd Materials 716-20, 761-70 (3rd ed. 1972) [hereinafter cited as Jennings \& Marsh]; Jennings, The New York Stock Exchange \& the Commission R'ate Struggle, 53 CaLIF. L. REv. 1119 (1965).

191. Thill Securities Corp. v. NYSE, 433 F.2d 264 (7th Cir. 1970), cert. denied, 401 U.S. 994 (1971).

192. See generally Jennings \& MARSH, supra note 190, at 720-31.

193. Two earker cases challenging the rules on limited membership and nonmember access, which apparently never got to trial, were Jefferies \& Co. v. NYSE, CCH FED. SEc. L. REP. \ 93,257 (S.D.N.Y. 1971), and Shumate \& Co. v. NYSE, CCH FED. SEc. L. REP. If 93,037 (N.D. Tex. 1971). The Gordon court held that challenges to limited exchange access rules were "frivolous," since section $3(a)(3)$ so clearly contemplates limitations on membership and nonmember access. 498 F.2d at 1304 n.5.

194. Robert W. Stark, Jr., Inc. v. NYSE, 346 F. Supp. 217 (S.D.N.Y.), aff'd, 466 F.2d 743 (2d Cir. 1972). The court held that NYSE Rule 318, 2 CCH NYSE GUiDe If 2318 (1975), which required that the primary purpose of a member must be serving the public as a broker-dealer, came within the scope of section 19(b) because a captive brokerage house was a device to reduce commissions paid. 346 F. Supp. at 227.

SEA Rule 19b-2, also embodying a primary purpose test, was unsuccessfully challenged in Philadelphia-Baltimore-Washington Stock Exch., Inc. v. SEC, 485 F.2d 718 (3d Cir. 1973), where the court held that such rules were not "orders" subject to review under 15 U.S.C. $\$ 78 y$ (a) (1970).

195. Haddad v. Crosby Corp., 374 F. Supp. 95 (D.D.C. 1973), cert. denied Gross v. National Ass'n of Sec. Dealers, Inc., 43 U.S.L.W. 3209 (U.S. Oct. 15, 1974) (No. 73-1968); United States v. National Ass'n of Sec. Dealers, Inc., 374 F. Supp. 95 (D.D.C. 1973), prob. juris. noted, 43 U.S.L.W. 3207 (U.S. Oct. 15, 1974) (No. 73-1701).

The system of cumulative quantity discounts in the sale of mutual fund shares had earlier been held immune from attack under the Robinson-Patman Act, 15 U.S.C. $\$ 13$ (1970). Baum v. Investors Diversified Servs., Inc., 286 F. Supp. 914 (N.D. I1. 1968), aff'd on other grounds, 409 F.2d 872 (7th Cir. 1969).

196. 15 U.S.C. $\& 78 \mathrm{~s}(\mathrm{~b})(1970)$. The text is as follows:

The Commission is further authorized, if after making appropriate request in writing to a national securities exchange that such exchange effect on its own behalf specified changes in its rules and practices, and after appropriate notice and opportumity for hearing, the Commission determines that such exchange has not made the changes so requested, and that such changes are necessary or appropriate for the protection of investors or to insure fair dealing in securities traded in upon such exchange or to insure fair administration of such exchange, by rules or regulations or by order to alter or supplement the 
empowered the SEC to alter rules governing problems of structure but not to adjudicate individual violations of such rules. ${ }^{197}$ There was no requirement of active supervision; indeed, the power seems only to have been actively asserted four times in the history of the agency. ${ }^{198}$ The list of reviewable items was limited, and many exchange rules were beyond the power of the SEC to change. ${ }^{199}$

Silver announced the principle for resolving apparent conflicts between the 1934 Act and the antitrust laws when applied to exchange rules and conduct:

Repeal [of the antitrust laws] is to be regarded as implied only if necessary to make the Securities Exchange Act work, and even then only to the minimum extent necessary. ${ }^{200}$

The case did not distinguish between rules reviewable under section 19(b) and other rules, but proposed this general test to solve all of the problems resulting from the absence of an express immunizing pro-

\begin{abstract}
rules of such exchange (insofar as necessary or appropriate to effect such changes) in respect of such matters as (1) safeguards in respect of the financial responsibility of members and adequate provision against the evasion of financial responsibility through the use of corporate forms or special partnerships; (2) the limitation or prohibition of the registration or trading in any security within a specified period after the issuance or primary distribution thereof; (3) the listing or striking from listing of any security; (4) hours of trading; (5) the manner, method, and place of soliciting business; (6) fictitious or numbered accounts; (7) the time and method of making settlements, payments, and deliveries and of closing accounts; (8) the reporting of transactions on the excliange and upon tickers inaintained by or with the consent of the exchange, including the method of reporting short sales, stopped sales, sales of securities of issuers in default, bankruptcy or receivership, and sales involving other special circumstances; (9) the fixing of reasonable rates of commission, interest, listing, and other changes; (10) minimum units of trading; (11) oddlot purchases and sales; (12) minimum deposits on margin accounts; and (13) similar matters.
\end{abstract}

The Reform Act, supra note 165, revised section 19(b) and added section 19(c) giving the SEC power to amend any exchange rule. This action is subject to judicial review under section 25(b) of the SEA as revised by Reform Act $\$ 20$.

197. See note 182 supra.

198. The SEC has abrogated only one rule under its section 19(b) powers on the ground that the effect was anticompetitive. In re Rules of the New York Stock Exchange, 10 S.E.C. 270 (1941). The rule in question prohibited NYSE members from acting as odd-lot dealers or specialists in NYSE listed stocks on the regional exchanges.

Three regulations have been adopted under section 19(b), dealing with off-floor trading (SEC Securities Exchange Act Release No. 7981 (Oct. 30, 1966)), institutional membership (SEC Securities Exchange Act Release No. 9950 (Jan. 16, 1973), modified by SEC Securities Exchange Act Release No. 10,052 (Mar. 22, 1973)), and negotiated comunission rates (SEC Securities Exchange Act Release No. 11,203 (Jan. 23, 1975)).

199. For example, Rule 405, 2 CCH NYSE GUIDE I 2405 (1975), which requires due diligence by brokers in learning the essential facts about each customer, does not scem to relate to any of the items listed in section 19(b).

200. 373 U.S. at 357 (emphasis added). There is no immunity where the "anticompetitive acts of the exchanges . . . conflict with their duty" under the Act, or where immunity "would defeat the congressional policy reflected in the antitrust laws without serving the policy of the Securities Exchange Act." Id. at 360. 
vision in the SEA. ${ }^{201}$ Other formulations of the "necessary" rule used in the Silver opinion include: immunity is implied where conduct is "within the scope and purposes" of the SEA ${ }^{202}$ or where any "policy reflected" in the SEA is served by the conduct. ${ }^{203}$

The first two cases to follow Silver laid down the bounds of inquiry without applying the "necessary" test or engaging in primary jurisdiction analysis. In Kaplan v. Lehman Brothers, ${ }^{204}$ the fixed minimum commission system was lield not to be a per se antitrust violation because it is sheltered under the SEC rulemaking powers, while in Thill Securities Corp. v. New York Stock Exchange, ${ }^{205}$ the SEC's supervisory powers over rate regulation were lield not to provide blanket immumity for the NYSE's anti-rebate rule. ${ }^{208}$ The Thill court directed the district court to build up a factual basis for resolving whether or not the "necessary" test was inet. ${ }^{207}$

The "necessary" test was subsequently applied in Gordon v. New York Stock Exchange, Inc. ${ }^{208}$ which lield that the fixed minimum commission system was exempt from the antitrust laws and within the exclusive jurisdiction of the SEC. The Second Circuit, interpreting the legislative language and intent, found that:

Congress vested in the Commission the power to determine whether change are "necessary" in the exchanges' rate-fixing practices to assure fulfillment of the goals of the Act. Accordingly, Congress de-

201. The only express immunity provision in the Act is section $15 A(n)$, part of the Maloney Act regulating activities of the NASD, which states: "If any provision of this section is in conflict with any provision of any law of the United States in force on June 25,1938 , the provision of this section shall prevail." 15 U.S.C. $\S 780-3(\mathrm{n})$ (1970). This language does not create a general power of immunity for disciplinary actions of the NASD, but insulates from antitrust attack those structural restraints on conipetition allowed in the section-notably the price fixing arrangements under 15 U.S.C. \$ 78o-3(i) (1970). Harwell v. Growth Programs, Inc., 459 F.2d 461 (5th Cir. 1971), cert. denied, 409 U.S. 876 (1972). See Note, Antitrust Immunity of the National Association of Securities Dealers under the Maloney Act, 14 B.C. IND. \& CoM.

L. REv. 111, 129-31 (1972).

202. 373 U.S. at 361 .

203. Id. at 360 .

204. 250 F. Supp. 562 (N.D. III. 1966), aff'd, 371 F.2d 409 (7th Cir. 1967), cert. denied, 390 U.S. 912 (1967).

205. 433 F.2d 264 (7th Cir. 1970), cert. denied, 401 U.S. 994 (1971).

206. 433 F.2d at 270 . The court stated that there was "no evidence as to the extent to which the challenged rule is subject to actual review by the SEC" and by imphcation decided that the rule did not fall within the scope of section 19(b).

207. On remand, the district court denied a motion for primary jurisdiction, which denial was held then to be non-appealable under 28 U.S.C. $\$ 1291$ (1970). Thill Sec. Corp. v. NYSE, 469 F.2d 14 (7th Cir. 1972). It then ordered the SEC and the Justice Department to produce certain formal opinions and factual memoranda relating to whether or not the anti-rebate rule was necessary to achieve the purposes of the Act. 57 F.R.D. 133 (E.D. Wis. 1972).

208. 498 F.2d 1303 (2d Cir. 1974), cert. granted, 43 U.S.L.W. 3290 (U.S. Nov. 
fined in $\S 19$ (b) those matters fundamental to achieving "the aims of the Securities Exchange Act," [citing Silver], and accorded the SEC the authority to make whatever changes respecting those matters are "necessary or appropriate" ( $(19(b))$ to effectuate those aims-i.e., in the terms of the Silver test, "necessary to make the Securities Exchange Act work." 209

Moreover, Congress in section 19(b)(9) expressly permitted "the fixing of reasonable rates of commission, interest, listing, and other charges." 210

Thus, the court held that its result was "mandated" by the language and history of the SEA ${ }^{211}$ and was explicitly not based upon the " "primary' jurisdiction" of the SEC. 212 Resort to the SEC was the plaintiff's exclusive remedy; the complaint did not state a cause of action before the court since its role would be solely one of judicial review of SEC rulemaking using an "arbitrary or capricious" standard. ${ }^{213}$ By emphasizing that the holding was not one of "primary" jurisdiction, the court wished to rule out any implication that its dismissal would allow the wider judicial review appropriate when a court exercises its "secondary" jurisdiction under an arguably lawful or material aid deferral rationale.

The Second Circuit buttressed its holding with arguments based upon the need for uniformity and the value of expertise, said to be "sound policy considerations governing regulation of the securities industry."214 A conflict between court and agency was a very real possibility because of efforts of the SEC to move towards competitive coinmission rates, efforts which the court recounts at length. ${ }^{215}$ Expertise was considered even more important because the questions were "not of the sort which courts can answer as well as the SEC."216 Because

18, 1974) (No. 74-304).

209. Id. at 1306 .

210. Id. at 1307 (emphasis added by court); 15 U.S.C. $\S 78 \mathrm{~s}(\mathrm{~b})(9)(1970)$.

211. $498 \mathrm{~F} .2 \mathrm{~d}$ at $1305-07$.

212. Id. at 1309 n.8.

213. Id. at 1311; APA, 5 U.S.C. $\$ 706$ (1970); 15 U.S.C. $\$ 78 \mathrm{y}(1970)$. See also Independent Broker-Dealers' Trade Ass'n v. SEC, 442 F.2d 132, 140 n.11 (D.C. Cir.), cert. denied, 404 U.S. 828 (1971); Natural Resources Defense Council v. SEC, CCH FED. SEC. L. REP. \ 94,910 (D.D.C. 1974).

214. 498 U.S. at 1307.

215. Id. at 1308-09.

216. Id. at 1310. The Gordon solution to the fixed mimimum commissions problem was expressily rejected in Fredrickson v. Merrill Lynch, Pierce, Fenner \& Smith, Inc., CCH FrD. SEC. L. REP. I 94,792 (N.D. IIl. 1974) which denied a motion to dismiss or stay based essentially upon the dicta of Thill that SEC jurisdiction does not preclude antitrust jurisdiction. 433 F.2d at 269. The court indicated a deference to the views of the SEC, but made clear that the agency could not bootstrap its way into exclnsive jurisdiction by purporting to regulate, when in the opmion of the court the price-fixing was not mandated by statute. 
the SEA is quite clear on the commission issue, the result in Gordon is correct. To the extent that other structural issues are not biterally covered by section 19(b), or perhaps where the SEC has not actively exercised supervision, the agency's power of exclusive jurisdiction may not be so apparent. This was arguably the situation in Thill.

A case has not yet arisen under the SEA which recognized exclusive jurisdiction over an issue while staying the remainder of the case. This would be the proper treatment if the case involved a challenge to a rule which was clearly within section $19(\mathrm{~b})$, such as the commission system in Gordon, and which also alleged that the rule had been selectively violated with an anticompetitive purpose. Rules with respect to which such a result might be possible are those dealing with financial responsibility, manner of soliciting business, or reporting of transactions. ${ }^{217}$

\section{Violations of the Act or Rules}

Because courts have been absorbed in antitrust issues, very little attention has been given to questions of exclusive jurisdiction over violations of the SEA or rules thereunder. The issue of rule validity must be clearly distinguished from the question of violation. Ricci referred only the violation issue to the agency, reserving to the court the decision on validity of the rule. The pattern in the SEA context is nearly the reverse. Clearly, the SEC has some exclusive jurisdiction over approval of rules, but there is very little authority for asserting that an SEC determination of liability for rule violations is a prerequisite to a successful suit for damages. ${ }^{218}$ Even though the SEC has a disciplinary mechanism exactly like that involved in Ricci, assuming it has power to prosecute an exchange for not enforcing its own rules, ${ }^{210}$ the results of the SEC procedure would not necessarily be binding as to the issues actually disposed of by its decision. ${ }^{220}$ Considerations which go imto the assessment of requests for remedies as divergent as imjunction, dannages and withdrawal of registration are so disparate that it would be inappropriate to assign a bimding effect to a prior agency resolution on the facts.

A somewhat stronger argument for exclusive jurisdietion over adjudications can be made where the violation is of a technical regula-

217. 15 U.S.C. $\$ \S 78 \mathrm{~s}(\mathrm{~b})(1), 78 \mathrm{~s}(\mathrm{~b})(5), 78 \mathrm{~s}(\mathrm{~b})(8)(1970)$.

218. Cf. Susquehanna Corp. v. Pan Am. Sulphur Co., 423 F.2d 1075, 1086 n.13 (5th Cir. 1970). For a case in which the SEC refused to investigate, see Project on Corporate Responsibility v. SEC, CCH FED. SEC. L. REP. đf 93,783 (D.C. Cir. 1972). Such a refusal cannot bar a court determination of violation of the Act or regulations.

219. See note 185 supra.

220. See text accompanying note 144 supra. 
tion closely wedded to some form of ongoing policy-making or experimentation. Even then the status of agency jurisdiction is inore properly classified as one over "arguably lawful" conduct in the Carnation sense.

\section{Arguably Lawful Conduct}

The flexibility of the "arguably lawful" analysis is illustrated by the application of this technique to borderline problems of statutory construction under the SEA. There are three areas of ambiguity for which such analysis provides a means of intelligent resolution: clallenges to section 19(b) rules and other structural exchange rules; anticompetitive conduct allegedly immunized by compliance with rules; and violation issues which may create a "risk of interference" with agency policymaking.

\section{Structural Exchange Rules}

Thill ${ }^{21}$ provides a perfect example of narrow statutory construction used to defeat deferral (regarding the immunity of the anti-rebate rule) where the Carnation "arguably lawful" test should liave mandated it. Some arguinent can be made that the language of section 19(b)(9) is less clear with respect to this rule than to the minimum commission system treated in Kaplan and Gordon, but this is a weak position considering the other cases which have construed rules to fit within that provision. ${ }^{222}$ The contention that the rule was not necessary on its face because it was often breaclied ${ }^{223}$ also fails to take into account the policies which underlay the Carnation decision. A better view is that the issue of rule validity per se should have been split froin the case and referred to the SEC for evaluation, because the rebate practices were an integral part of the commission problem which the agency was imvestigating. ${ }^{224}$ Even though most exchange rules, including those deal-

221. Thill Sec. Corp. v. NYSE, 433 F.2d 264 (7th Cir. 1970), cert. denied, 401 U.S. 994 (1971).

222. See, e.g., Robert W. Stark, Jr., Inc. v. NYSE, 466 F.2d 743 (2d Cir.), aff'g, 346 F. Supp. 217 (S.D.N.Y. 1972) (rule against memberships by those institutions not having the primary purpose of serving the public as broker-dealers); Abbott Sec. Corp. v. NYSE, 384 F. Supp. 668 (D.D.C. 1974) (rule against "give-ups," or sharing of coinmissions with another exchange member in return for investment services).

223. 433 F.2d at 273-74.

224. Circuit Judge Pell dissented in part, urging that the Kaplan case required elimination of the matter of the validity of the exchange rule per se from the remand proceedings. 433 F.2d at 277-78. This view is motivated by a concern for uniformity; it would be absurd to have the SEC approve such a central rule and have an antitrust court at the same time disapprove it. This rationale does not extend to alleged discrimination in enforcenent which, as Judge Pell conceded, creates genuine issues of fact under the Silver necessity test.

The Gordon court stated that the anti-rebate rule was not significantly different from the minimum fixed commission rule and would appropriately fall within the "sim- 
ing with disciplinary proceedings contemplated by section $6(\mathrm{~b}),{ }^{225}$ were not reviewable under section 19(b), doubts should have been resolved in favor of agency review under a "risk of interference" theory.

\section{Anticompetitive Conduct and Discriminatory Enforcement of Ex- change Rules}

Allegations that otherwise valid exchange rules have been selectively enforced can present another circumstance calling for application of the Carnation "arguably lawful" analysis. SEC jurisdiction to review such rule violations is based on sections $19(a)(1)$ or 19(a)(3) of the SEA. ${ }^{226}$

Thill is the principal case illustrating the possibility of discriminatory enforcement of excliange rules. The plaintiff alleged "various sophisticated devices whereby favored nonmembers had the practical effect of rebates." ${ }^{227}$ Such selective enforcement had allegedly been used as a weapon against particular competitors. ${ }^{228}$ While the SEC arguably had the power to regulate competition in accordance with the statute, it lacked authority to sanction such discrimination, and it had not treated such practices as violations of the exchange rule.

Allegations such as these, if proved, would justify antitrust enforcement even in an otherwise regulated industry. ${ }^{220}$ These practices seem at first glance to be clearly unlawful, but there must be a serious inquiry into whether immediate judicial resolution of the viola-

ilar matters" category of section 19 (b)(13) (15 U.S.C. $\$ 78 \mathrm{~s}(\mathrm{~b})(13)$ (1970)). Gordon v. NYSE, 498 F.2d 1303, 1310 n.10 (2d Cir. 1974).

225. 15 U.S.C. $\& 78 f(b)$ (1970). The rules night have been reviewable by the SEC when the exchange was first registered, but there was no continuing procedure whereby the SEC reviewed them as they were modified or interpreted. For the recent change amplifying the SEC's power in this regard, see note 189 supra.

226. 15 U.S.C. $\$ \S 78 \mathrm{~s}(\mathrm{a})(1), 78 \mathrm{~s}(\mathrm{a})(3)(1970)$. These provisions do not allow proceedings against exchange members for violations of exchange rules, so the posture must be that of disciplining the exchange for not enforcing its own rules. See note 185 supra.

227. 433 F.2d at 278 (Pell, J., concurring and dissenting).

228. Id. at 270. The alleged practices included advertising and oral persuasion aimed at undermining customers' confidence in nonmember broker-dealers. Id. at 27475.

229. Silver defined the role of antitrust laws in this context as "insuring that an exchange will not in soine cases apply its rules so as to do injury to coinpetition which cannot be justified as furthering legitimate self-regulative ends." 373 U.S. at 358 . Thus, SEC approval of a broad rule might not bar adjudication by a court of those cases where anticompetitive purpose is alleged in spite of technical compliance. This was one of the problems in Ricci, where the exchange rule was so vague that even the majority conceded that the immunity issue would be decided in court. 409 U.S. at 305-06. In the securities setting there are still risks of interfering with the rule-1naking power of the SEC, for a court might use a determination of violation to in effect overrule a basic structural restraint of the Act. Such action would violate the statutory allocation of powers with respect to structural rules under section 19(b). 
tion issue might conflict with SEC authority. This would be the case if: (1) the rules were not in fact being breached; (2) the SEC might approve such a fragmented rebate system under section 19(b) when given a chance; or (3) this cause of action served as a cover for attacking the rule itself. Thus the Thill court should have given more serious consideration to the Carnation test before dismissing the possibility of immunity even as to practices which on first impression did not seem to be arguably protected..$^{230}$ The court also had the option of retaining jurisdiction over certain issues while deferring on others. ${ }^{231}$

\section{Adjudicative Interpretation of SEC Regulations}

Similar problems and results can be seen with respect to violation issues which do not involve any antitrust challenge. Although the SEC does not have exclusive jurisdiction over violation issues even if there is an available adjudication procedure, there are certain risks of conflict between court and agency action which favor stay of a violation issue until the SEC has acted. This imight be true if the substantive basis of the cause of action is a regulation which is tentative or experimental. ${ }^{232}$ In this instance deferral could be based on the expertise rationale of Western Pacific ${ }^{233}$ interpretation of a regulation in the context of adjudicative proceedings may be inseparable from the agency's power to promulgate the substantive standards in the first instance. Where a complex factual pattern must be explored in order to interpret language im a regulation, and interpretation affects the manner in which the provision fits into the regulatory scheme, the SEC

230. Thill's majority did not direct the district court to consider the primary jurisdiction question before reaching the merits. Chief Judge Swygert, concurring in the reversal, urged that this question was still unresolved and attempted to "indicate relevant lines of inquiry on remand . . ." 433 F.2d at 275. The fourth point of his test comes closest to a "risk of interference" theory: the possibility of achieving antitrust aims "without subjecting the exchanges to treble damages suits." Id. at 277.

231. See, e.g., Abbott Sec. Corp. v. NYSE, 384 F. Supp. 668, 670 (D.D.C. 1974) (retaining jurisdiction only over the allegation that the defendants conspired to retain $100 \%$ of the brokerage commissions earned on certain orders). As was evident in Ricci and Deaktor, a "conspiracy" may be "arguably lawful" so the analysis must proceed to consider deferral on the Carnation test. See also the discussion of Zuckerman v. Yount, 362 F. Supp. 858 (N.D. III. 1973), in note 249 infra.

232. The argument that the SEC's administrative scheme is a complicated whole in which the courts should not overly meddle is set forth in W. CARY, Politics AND THE Regulatory Agencres 127-34 (1967). See also Cary, Rulemaking and Administration, 23 AD. L. Rev. 387, 393-94 (1971); Cohen \& Rabin, Broker-Dealer Selling Practice Standards: The Importance of Administrative Adjudication in Their Development, 29 LAW \& CONTEMP. ProB. 691 (1964). Uniformity arguments made there are just as applicable to a finding of primary jurisdiction under the risk of interference theory. Some of the arguments made by the Gordon court also relate to this concept of deferring to concurrent rule-making proceedings. See text accompanying notes 214-16 supra.

233. United States v. Western Pac. R.R., 352 U.S. 59, 66-68 (1956). 
may arguably have power to establish that interpretation. On the other hand, the Merchants "question of law" approach ${ }^{234}$ would apply to most established regulations. The risk of interference will be high only for comparatively rare cases in which the regulations are new and lave not achieved a settled administrative interpretation.

\section{E. Material Aid}

The material aid test is appropriate to the securities setting since almost all of the regulatory circumstances which underlie Ricci are present in this industry. A section 19 (a)(1) proceeding is directly parallel to the procedure which the Ricci court utilized: a hearing to suspend an exchange for violations of the SEA or excliange regulations or for not enforcing its own rules. ${ }^{235}$ Section 19(a)(3), allowing discipline of members and officers for violations of the SEA and regulations, also provides an agency forum for court referral.

The recent reform bill expands SEC powers to include review of exchange disciplinary actions ${ }^{233}$ and clrange of any selfregulatory rule. ${ }^{237}$ Increased SEC jurisdiction will result in some judicial deferral based on the doctrine of exhaustion, insofar as those remedies are the gravamen of a court case. Any anticompetitive challenges can be raised at the stage of judicial review. ${ }^{238}$

To the extent that rehef sought is not the abolition of an exchange rule, these new procedures will provide avenues for a court to deal flexibly with issues which are arguably lawful in the Ricci sense. For instance, a cliarge of discriminatory violation of rules may be routed through an exchange disciplinary proceeding, followed by SEC review and return of the case to court. The procedures provide the option of using the agency; the vital question is then whether deferral inaterially aids the court, justifying such use.

\section{Complaints Against Exchange Rules}

The test which a reviewing court uses may determine the materiality of aid afforded by deferral. In Silver, the Court used a strict necessity test, which in effect meant that the exchange had to prove an inability to function without the contested rule. There could be no

234. Great N. Ry. v. Merchants Elevator Co., 259 U.S. 285 (1922).

235. 15 U.S.C. $\& 78 \mathrm{~s}(\mathrm{a})(1)(1970)$. The latter ground must be implied under the SEA, while it is explicit under the CEA, 7 U.S.C. $\$ 8$ (1970). There is authority for such an imphication, as indicated in note 185 supra, and the reform bill makes this power exphicit. Reform Act, supra note $165, \$ 16$.

236. Reform Act, supra note $165, \$ 16$.

237. Id.

238. Id. New section 25(b) establishes limited judicial review, i.e., a substantial evidence test as to factual findings, of the SEC's actions with respect to direct challenges to rules. No mention is made of the weight to be given to competitive considerations. 
justification, the Court held, for denying wire connection applications without a notice and hearing. ${ }^{239}$ This decision was reached without any inquiry into the views of the SEC, the valid reasons for having such a rule, violation of the rule by the NYSE, or the exchange's basis for denying the inembers' applications. A court using such an immunity test has no need for input from the SEC. It is unlikely that any information the SEC could provide would be sufficient to overcome the presumption of invalidity.

Some subsequent decisions have involved the use of a test which emphasized the facts of the particular case and the workability of the regulatory scheme, however, making the possibilities for material aid evident. A summary suspension for net capital violations, without a prior opportumity to be heard, was upheld in J.R. Williston \& Beane, Inc. $v$. Haack. ${ }^{240}$ The court found the rules in question to be "justified in furthering legitimate self-regulative ends, ${ }^{, 241}$ namely, assuring member financial responsibility. A vital reason for such rules is the need to avoid fanning rumors of trouble in the Street. The seriousness of the situation with respect to this particular plaintiff was critical to the decision..$^{242}$

In Crimmins v. American Stock Exchange, Inc. ${ }^{243}$ the court denied a preliminary injunction against disciplinary proceedings which did not include a right to counsel at the fimal hearings. The exchange's action was held not to violate due process, to be fair in fact, and to satisfy the Silver test. The demial of counsel was found necessary to carry out the self-policing policy of the SEA by allowing the exchange promptly to root out violators of ethical rules. ${ }^{244}$

A similar case reaching a result in favor of immunity was Jacobi v. Bache \& Co., Inc. ${ }^{245}$ The court found that it had jurisdiction because

239. Silver v. NYSE, 373 U.S. 341,361 (1963).

240. CCH FED. SEC. L. REP. \ 94,921 (S.D.N.Y. 1974).

241. Id. at 97,166, quoting Silver, 373 U.S. 341, 358 (1963). The suspensions were pursuant to NYSE Const. art. XIII, $\$ 2$ and NYSE Rule 325(a). 2 CCH NYSE GUIDE II 1602, 2325 (1975).

242. The plaintiff here had arrived at its net capital problems because of its involvement in the great salad oil scandal of 1963. CCH FED. SEC. L. REP. If 94,921, at 97162.

243. 346 F. Supp. 1256 (S.D.N.Y. 1972). The plaintiff had been given ample opportunity to consult with counsel beforehand and to present any defense in person at the hearing.

244. Id. at 1260.

245. 377 F. Supp. 86 (S.D.N.Y. 1974). Plaintiffs alleged that the NYSE rule which excluded the $\$ 15$ temporary service charge from the calculation of compensation of registered representatives was designed to reduce competition for the services of such persons. NYSE Const. art. XV, \& 1 and NYSE Rule 347(a), 2 CCH NYSE GUDE III 1701, 2347 (1975). An earlier aspect of this same dispute was decided in Cordova v. Bache \& Co., 321 F. Supp. 600 (S.D.N.Y. 1970). 
the SEC had disclaimed "primary responsibility" for the dispute, ${ }^{240}$ and the basic allegation related to the manner in which a compensation rule affected the employment relationship. ${ }^{247}$ The complaint was dismissed on the merits because the court did not find any anticompetitive purpose or effect in the rule. The restriction was also found consistent with one aim of the securities laws-financial responsibility of brokerage houses. ${ }^{248}$

These cases have not approached the issues in primary jurisdiction terms. Nonetheless, they have contributed to the doctrine by developing an attitude of deference to the comprehensiveness of the regulatory scheme and a broad reading of what is necessary to make the SEA work. Except for Silver, they apply a "rule of reason" or "business justification" standard of review. ${ }^{249}$ By analogy, preliminary deferral for agency factfinding and recommendations would certainly be of material aid. ${ }^{250}$ The rules may be vague and require a full understanding of the operating background for their appraisal, or they may be very technical and require complex economic knowledge for a proper evaluation. Moreover, there is clearly some possibility that cases may be disposed of at the agency level.

\section{Immunity of Anticompetitive Conduct}

Thill ${ }^{251}$ provides a fascinating study in the possibilities of material aid deferral because of the variety of issues present in the case. While

246. 377 F. Supp. at 93.

247. Id.

248. Id. at 97. The SEC had registered its non-objection to the imposition of the charge for 90 days. SEC Securities Exchange Act Release No. 8860 (April 2, 1970).

249. Cf. Intercontinental Indus., Inc. v. American Stock Exch., 452 F.2d 935, 940 . 41 (5th Cir. 1971) (dehisting procedure); Dickstein v. duPont, 443 F.2d 783 (1st Cir. 1971) (arbitration rule); Cowen v. NYSE, 371 F.2d 661 (2d Cir. 1967); Rich v. NYSE, 379 F. Supp. 1122 (S.D.N.Y. 1974); Rust v. Drexel Firestone Inc., 352 F. Supp. 715 (S.D.N.Y. 1972); Jacobson v. American Stock Exch., CCH FED. SEC. L. REp. If 93,131 (S.D.N.Y. 1971) (no-counsel rule). See also Zuckerman v. Yount, 362 F. Supp. 858 (N.D. I11. 1973). In that case, an anti-competitive conspiracy in conformance with a rule was alleged. The court denied summary judgment for the plaintiff, because the necessity for the rule and due process were questions which had to be decided on a factual basis. Id. at 861-63. It then noted that review of an anticompetitive application of rules would proceed on a good faith standard, not one of substitution of judgment. Id. at 863.

250. The only analogous use of material aid deferral relating to exchange rule problems has been a request by the court in the commodities minimum commission cases for the Administrator of the Commodity Exchange Authority to report his views on the necessity, reasonableness, impact, and economic implications of alternative proposals for change of the commission rules. United States v. Board of Trade, 1972 Trade CAs. II 73,831 (N.D. Ill.). The case was stayed for 120 days to allow this report. This was not a use of primary jurisdiction as such, but merely a solicitation of views, yet the action was clearly founded upon some of the same considerations present in Ricci.

251. Thill Sec. Corp. v. NYSE, 433 F.2d 264 (7th Cir. 1970), cert. denied, 401 U.S. 994 (1971). 
soine parts of the opinion indicate a bias against immunity, ${ }^{262}$ the decision was a directive to the district court to develop detailed evidence on several factual matters in order to reach a sensitive application of the Silver necessity test. The factual questions which had to be answered included: What was the effect of the conduct? Did the SEC exercise actual review of the rule and weigh conpetitive considerations in such review? Why was the rule necessary and what would happen if it were abolished? Was there in fact a pattern of discriminatory apphication and evasions of the rule? Finally, were certain practices based upon a predatory purpose?253 Once the questions relevant to evaluating implied immunity are posed in this way the benefits of a Ricci solution are evident.

Ricci's preliminary tests were satisfied in Thill: there was an area of immunity uncertain in its extent; there was a claim of contpliance with the rule and justification for it; and there was an available SEC procedure (section 19(a)(1)). A 19(b) procedure for evaluating the rule per se could also provide valuable information about the purpose and necessity of the rule. The purpose of deferral is not to solve the antitrust issues but to provide a background of facts and administrative views as an aid to court decision on the questions of predatory intent and discriminatory application. The court's doubt about the existence of a violation and lack of confidence in applying the anti-rebate rule to the conduct in the case indicate that deferral would have been beneficial, even if the issues were not of the inost complex economic variety. A need for expertise is also evidenced by the bewildering number of evasive devices ${ }^{254}$ and the fact that a rebate system is an integral part of the commission structure.

A consideration of the value of expertise in evaluating violations of the rule shows that the violation question is inseparable from the validity of the rule itself. All of the considerations and experience which the SEC would apply in a 19(b) proceeding to evaluate the rule are applicable to interpreting what conduct is within the protection of the rule. When such a simple black letter rule covers a complex pattern of practices, serious doubt is raised about the propriety of a court holding that a violation is present without hearing the agency view. As in Ricci, unwritten rules and extralegal controls are the nub of the controversy, and what seems at first glance to be discrimination may be

252. Id. at 272-73. The court made much of the great economic power of the NYSE, the national commitment to competitive pricing, the SEC's passive role in approving commission rate increases, and the generalization that agencies tend to become "dominated" by the industry they regulate.

253. Id. at 274-75.

254. Id. at 274. See generally Bicks, Antitrust and the New York Stock Exchange, 21 Bus. LAw. 129 (1965); Jennings, supra note 190. 
within the realm of what the agency intended to approve or would condone if asked.

Allocation of court resources had some bearing on primary jurisdiction in Thill. Strong arguments against deferral were based on economy of resources. The SEC had "ample opportunity" to take action in relation to the anti-rebate rule and had not been very active in its supervision of these claimed abuses. ${ }^{205}$ The agency's views were well known to the district court because the SEC was a party via intervention, and the court had already devoted substantial resources to the case by the time the primary jurisdiction issue was decided on remand. ${ }^{256}$ While there was little hope that an SEC proceeding would finally resolve the controversy, there was some possibility for simplifying the issues if the agency did find a pattern of unjustified violations.

Similar arguments indicate that the court could better decide conspiracy issues after the SEC completed its evaluation of alleged discriminatory practices. ${ }^{257}$ If the conspiracy amounted to nothing more than enforcenient of a rule which the SEC approved, the case for immunity would be established. If there were a pattern of discriminatory use of that rule, there would be an issue for the court to decide after obtaining the agency's view on violation and its interpretation of the rule.

\section{Violations of SEC Regulations}

Direct applications of Ricci and Deaktor are likely in the securities field, with respect to violations of regulations where busniess justification is a possible defense. Ricci referred a nnembership dispute with very little public significance to the agency, on the unspoken rationale that such disputes can be settled more efficiently through the administrative process. Although the Court made the case for aid to its own decisionmaking, it clearly hoped that the case would be finally resolved at the agency level. Similar problems in the securities field might arise over membership matters, although as we have seen the courts have been inost receptive to using the antitrust laws to hear these disputes. In such cases the rules are often phrased in general terms, with the real complexity consisting of the unwritten lore which has governed the industry. Once the defense is raised that the rules were followed, the

255. Post Trial Brief of Intervenor United States of America, Thill Sec. Corp. v. NYSE, Civ. No. 63-C-264 (E.D. Wis., May 1, 1973), in Hearings on the National Securities Market System Act of 1973, S. 2519, Before the Subcomm. on Securities of the Senate Comm. on Banking, Housing and Urban Affairs, 93d Cong., 1st Sess., at 207, 235 (1973).

256. See note 207 supra.

257. Cf. Abbott Sec. Corp. v. NYSE, 384 F. Supp. 668 (D.D.C. 1974). See note 231 supra. 
courts can use material aid deferral to route such minor cases to the administrative agency.

A similar result would seem to be called for where the violation of a very technical rule with very little broad social significance is alleged. Examples of these are the regulations relating to reporting and recordkeeping. ${ }^{258}$ In these cases there are no societal values which the courts must protect, and the administrative reinedy inay suffice. The courts' resources can best be conserved by confining their imvolvement to review. These are clear instances in which workload considerations could be decisive.

Deaktor could be applied in order to refer cases alleging manipulation in violation of sections 9 or 15(c). ${ }^{259}$ Mamipulation involves both an exceedingly complex factual situation and the need to exercise discretion as to prosecution. In almost every case there is soine colorable justification for the conduct which would make it legal. ${ }^{260}$ Simce the determinative test of whether or not the conduct is to be proscribed is its relation to normal behavior, ${ }^{261}$ a thorough understanding of the market background and informal practices is essential to the factfinder. The issue must be resolved by a technical inquiry rather than a moral judgment. There is hittle case authority guiding courts in this area, due to the difficulty of proving the requisite purpose. ${ }^{262}$ Since the agency made the regulations it would have a better understanding of the factors which influenced the choice of prohibitions set forth in them. Similar arguments-technical coinplexity coinbimed with the presence of a busmess justification - call for deferral of cases concerning floor trading practices, ${ }^{203}$ stabilization, ${ }^{264}$ hypothecation, ${ }^{265}$ net capital require-

258. 17 C.F.R. $\S \S 240.13 a-1$ to $-17,240.15 b 10-6$ (1974).

259. 15 U.S.C. $\$ \S 78 \mathrm{i}, 780$ (c) (1970).

260. See, e.g., United States v. Stein, 456 F.2d 844 (2d Cir. 1972), cert. denied, 405 U.S. 922 (1972) (clain of compliance with Rule 10b-7(g), 17 C.F.R. $\$ 240.10 \mathrm{~b}-$ 7 (g) (1970)); Crane Co. v. American Standards, Inc., 419 F.2d 787 (2d Cir. 1969), cert. denied, 400 U.S. 822 (1970) (claim of legitimate business purpose).

261. See generally Bloomenthal, Market-Makers, Manipulators and Shell Games, 45 ST. JohN's L. Rev. 597 (1971); Martin, Broker-Dealer Manipulation of the Over-theCounter Market-Toward a Reasonable Basis for Quotations, 25 Bus. LAw. 1463 (1970); Note, Manipulation of the Stock Markets under the Securities Laws, 99 U. PA. L. REV. 651 (1951); Note, Regulation of Stock Market Manipulation, 56 YALE L.J. 509 (1947), See also the sources cited in note 127 supra.

262. Jennings \& MARSH, supra note 190 , at 925 . Some of the few cases are United States v. Re, 336 F.2d 306, 309-10 (2d Cir.), cert. denied, 379 U.S. 904 (1964); United States v. Minuse, 142 F.2d 388, 389 (2d Cir.), cert. denied, 323 U.S. 716 (1944); Dorfman v. First Boston Corp., 336 F. Supp. 1089 (E.D. Pa. 1972); In re Halsey Stuart \& Co., 30 S.E.C. 106, 123-24 (1949); In re Kidder Peabody \& Co., 18 S.E.C. 559, 568 (1945); Jack Flettman, SEC Securities Exchange Act Release No. 8449 (Nov. 14, $1968)$.

263. SEA Rules 11a-1, 11b-1, 17 C.F.R. §§ 240.11a-1, 240.11b-1 (1974).

264. SEA Rules 10b-6, 10b-7, 17 C.F.R. $\$ \$ 240.10 b-6,240.10 b-7$ (1974).

265. SEA Rule 8c-1, 17 C.F.R. $§ 240.8 c-1$ (1974). 
ments, ${ }^{268}$ and unlisted trading privileges. ${ }^{267}$

An obvious question raised by the low quantum of aid required under Ricci and Deaktor is whether referral of an action under Rule $10 \mathrm{~b}-5^{268}$ or Rule $15 \mathrm{cl}-2^{268}$ would be beneficial. The SEA provides a procedure for adjudication before the SEC, and many such cases reach the courts as appeals of agency proceedings. ${ }^{270}$ Deferral could be used to route less important cases to the agency. The exclusive jurisdiction of the district courts would not be infringed because the case would be stayed and the referral would merely be advisory. The arguments against routine use of primary jurisdiction are the vast experience of the courts on this particular subject, the vagueness of the statute and the regulations as legal standards, and the expense and delay in connection with important cases. Agency bias against the plaintiff is not a factor because the SEC is a very tenacious prosecutor in its own right, but this may amount to bias against the defendant. In summary, there might be a place for the Ricci technique in the 10b-5 area, but it should be used sparingly.

\section{Violations of Exchange and NASD Rules}

The courts have been active in recent years in creating imphed civil rights of action for violation of self-regulatory rules. ${ }^{271}$ Such hability may be based upon the rationale that certain of these rules for the "protection of investors" serve as substitutes for direct regulation by the SEC. ${ }^{272}$ The Ricci test raises the possibility of finding that

266. 15 U.S.C. $\$ \$ 78 \mathrm{~h}(\mathrm{~b}), 78 o(\mathrm{c})(3)$ (1970); SEA Rule 15c3-1, 17 C.F.R. $\S$ 240.15c3-1 (1974).

267. SEA Rules $12 \mathrm{f}-1$ to $-7,17$ C.F.R. $\S \S 240.12 \mathrm{f}-1$ to -7 (1974).

268. 17 C.F.R. $\$ 240.10 b-5$ (1974).

269. 17 C.F.R. $\$ \S 240.15 c-1,-2$ (1974).

270. 15 U.S.C. $\$ \$ 780(b)(5), 78 s(a), 78 y(a)$ (1970). See, e.g., Berko v. SEC, 316 F.2d 137 (2d Cir. 1963); Norris \& Hirshberg, Inc. v. SEC, 177 F.2d 228 (D.C. Cir. 1949); Charles Hughes \& Co. v. SEC, 139 F.2d 434 (2d Cir. 1943), cert. denied, 321 U.S. 786 (1944).

271. SEC v. First Sec. Co., 463 F.2d 981 (7th Cir.), cert. denied, 409 U.S. 880 (1972); Avern Trust v. Clarke, 415 F.2d 1238 (7th Cir. 1969), cert. denied, 397 U.S. 963 (1970); Buttrey v. Merrill Lynch, Pierce, Fenner \& Smith, Inc., 410 F.2d 135 (7th Cir.), cert. denied, 396 U.S. 838 (1969).

Contra, Colonial Realty Corp. v. Bache \& Co., 358 F.2d 178 (2d Cir.), cert. denied, 385 U.S. 817 (1966); Utah v. duPont Walston, Inc., CCH Fed. SEC. L. Rep. \ 94,312 (D. Utah 1974); McMaster Hutchinson \& Co. v. Rothschild \& Co., CCH Fed. Sec. L. ReP. II 93,541 (N.D. Ill. 1972); Rospighiosi v. Clogher, 46 So. 2d 170 (Fla. 1950).

272. Wolfson \& Russo, The Stock Exchange Member: Liability for Violation of Stock Exchange Rules, 58 CALIF. L. Rev. 1120 (1970), See also Lowenfels, Private Enforcement in the Over-the-Counter Securities Markets: Implied Liabilities Based on NASD Rules, 51 CORNelc L.Q. 633 (1966); Hoblin, A Stock Broker's Implied Liability to Its Customer for Violation of a Rule of a Registered Stock Exchange, 39 ForDH. L. Rev. 253 (1970); Shipman, Two Current Questions Concerning Implied Private Rights Under the Exchange Act, 17 CASE W. RES. L. Rev. 925 (1966). 
primary jurisdiction over these cases lies with the exchanges or the NASD. While it is a novel idea that deferral can be to a body other than a government agency, the powers of these organizations have been described as delegated governmental powers. ${ }^{273}$ Moreover, under the recent reform bill, the SEC will review all of these cases before they return to the courts. ${ }^{274}$ Finally, the exchanges make and enforce rules just as the Commission does, and the NASD performs these functions over an even broader and less organized sphere of the securities market. Thus, these bodies possess the attributes of expertise which might be utilized for material aid deferral. In addition, those rules classified as merely ethical ${ }^{275}$ are prosecuted by the self-regulatory bodies exclusively; as to them no civil cause of action should be recognized.

Whether material aid actually calls for deferral in cases of rule violation depends largely upon the kind of rule violated. Those rules relating to the details of membership, clearing activities, and financial responsibility are best left to adjudication by the self-regulatory bodies in order to conserve court resources. Those rules relating to fraud and suitability are best retained for court resolution, because the issues to be resolved are not ones regarding which expertise is decisive.

Adjudication of violations of those rules which are detailed and present the potential for busimess justification may be referred to the exchanges or the NASD. Such issues would include manipulation, floor trading practices, and net capital rules. There is room for discretion in assessing all of these kinds of violations because the exigencies and precise details of a case may call for condoning what seems to be a breach of the black letter rules. An additional consideration is that bypassing the self-regulatory enforcement mechanism will tend to weaken the bodies which have the greatest capacity for flexibly and quickly adjusting controls to changing market conditions.

\section{F. Summary of Deferral Under the SEA}

Each of the three rationales for finding primary jurisdiction is suitable for different kinds of problems raised by the SEA. Exclusive jurisdiction is confined to the various administrative remedies and to the

273. Thill Sec. Corp. v. NYSE, 433 F.2d 264, 266 (7th Cir. 1970), cert. denied, 401 U.S. 994 (1971).

274. Reform Act, supra note $165, \S 16$. NASD proceedings are already reviewable under 15 U.S.C. $\$ \S 780-3(\mathrm{~g}), 780-3(\mathrm{~h})(1970)$.

275. Colonial Realty Corp. v. Bache \& Co., 358 F.2d 178, 182 (2d Cir.), cert. denied, 385 U.S. 817 (1966). See Note, Civil Liability for Violation of NASD Rules: SEC v. First Securities Co., 121 U. PA. L. Rev. 388, 393-94 (1972). 
rulemaking powers under section 19(b) among others. "Arguably lawful" analysis is suited for those violation questions which might impinge upon the quasi-legislative function and for those adjudications where a defense is raised of compliance with a rule or regulation. Deferral may be of material aid in assessing the validity of a defense based on business justification since the agency that promulgated the regulation has a better understanding of the scope and intent of its prohibitions. The actual decision on whether to utilize nonmandatory deferral to the SEC or self-regulatory bodies depends upon weighing of the material aid factors: the narrowness of fact questions, the need for background knowledge about the industry in resolving them, the relevance of extralegal and informal restraints to the conduct, the potential for elimination of issues, conservation of governmental resources, and any countervailing factors concerning the situation of the particular plaintiff.

\section{CONCLUSION}

Traditional primary jurisdiction doctrine relied heavily on statutory construction, especially regarding the theory of exclusive jurisdiction. Many of the problems in the application of exclusive jurisdiction could be solved by appropriate legislation. ${ }^{278}$ This would require that Congress make hard decisions on the basic issues of how much competition is desirable and which body should enforce and oversee approved restraints. Assignment of exclusive jurisdiction on an issue-by-issue basis would reduce conflicts and interference, thus making the regulatory schemes more workable.

The decision in Ricci extended judicial options to include deferral beyond what is required by statute. It focused the primary jurisdiction inquiry on the benefits which courts can expect to receive froin prior agency determinations and on the effects of deferral on the parties involved. The factors involved in this balancing process have not been fully articulated. They should include, however, benefits derived from analysis of facts and issues by an informed body, advisory opinions from the agency authorized by Congress to deal with closely related matters, and elimination of some cases froin the courts' workload, on the one hand, and costs such as possible inefficiency or duplication of effort im the dispute settlement mechanism as a whole (courts and agencies) and expense, delay, due process infringement, and agency bias arising from particular facts of a case, on the other. Countervailing factors were apparently very weak in Ricci, but subsequent case law may be expected to elaborate them and illummate the balancing process.

276. Cf. 3 DAvis, supra note $1, \S 19.05$ at 27; Handler, Regulation versus Competition, 43 ANTITRUST L.J. 277, 285, 291-93 (1974). 